\title{
Wealth of Flora and Vegetation in the La Campana-Peñuelas Biosphere Reserve, Valparaiso Region, Chile
}

\author{
Enrique Hauenstein \\ Catholic University of Temuco, Faculty of Natural Resources, Temuco
}

Chile

\section{Introduction}

Chile has a National System for State-Protected Wilderness Areas (Sistema Nacional de Áreas Silvestres Protegidas del Estado - SNASPE), which consists of three categories: National Parks (PN), National Reserves (RN) and Natural Monuments (MN). It presently contains 95 units, covering in total 19\% of the country's territory. SNASPE has become a fundamental pillar not only for safeguarding an important part of Chile's natural heritage but also for protecting and valuing our cultural heritage, particularly where it is integrated in the areas which make up this system (Oltremari, 2002). By 1985, UNESCO had designated 7 Biosphere Reserves in Chile: Lauca, Fray Jorge, Juan Fernández, La Campana-Peñuelas, Araucarias, Laguna San Rafael and Torres del Paine. To these were later added Cabo de Hornos [Cape Horn], Bosques Templados Lluviosos de los Andes [Wet Temperate Andean Forests], and recently Laguna del Laja-Nevados de Chillán.

The Valparaiso Region contains La Campana National Park, declared a Biosphere Reserve in February of 1985 jointly with Lago Peñuelas National Reserve due to their high biological and ecosystem diversity, representative of the mediterranean environments characteristic of this region (Weber, 1986; CONAF, 1992, 2008; Elórtegui \& Moreira, 2002). In 1834, during his stay in Chile, the great naturalist Charles Darwin climbed to the peak of La Campana where he was amazed by the presence of forests of palm trees (Jubaea chilensis), and especially by recording a specimen at 1,350 $\mathrm{m}$ above sea level (Elórtegui \& Moreira, 2002).

The central zone of Chile, also called the mesomorphic or mediterranean zone, extends approximately from $32^{\circ}$ to $37^{\circ} \mathrm{S}$ (Pisano, 1956). It has a mediterranean climate, which Koeppen $(1931,1948)$ classifies as a "warm-temperate climate with sufficient humidity", in the subdivision "winter rains and prolonged dry season", characterised by regular periods of rain in winter and a strongly marked dry season which may extend from six to eight months. This corresponds to other mediterranean zones around the world such as in California and southern Europe in the Northern Hemisphere, and Australia and southern Africa in the Southern Hemisphere (Grau 1992; Arroyo et al., 1995). The climatic conditions mean that the vegetation in these regions has specially adapted characteristics, such as the presence of sclerophyllous leaves, lignotubers and a great capacity for water-use efficiency (Money \& Kumerow, 1971; Araya \& Avila, 1981; Avila et al., 1981). According to 
Marticorena et al. (1995), the central zone of Chile is a focus where endemic species are concentrated, with great wealth and diversity of flora. Mittermeier et al. (1998) indicate the presence of 1,800 species of endemic plants for this area, leading it to be considered as one of the world's 25 hotspots, requiring priority protection (WWF \& IUCN, 1997; Myers et al., 2000).

In this context, flora and vegetation studies are essential basic elements for developing proposals for the conservation and management of species and ecosystems, or defining priority areas (Cavieres et al., 2001; Teillier et al., 2005). The object of the present study is to contribute to knowledge of the flora and vegetation of the La Campana-Peñuelas Biosphere Reserve.

\section{Methods and results}

\subsection{Study area}

This Biosphere Reserve includes La Campana National Park $\left(32^{\circ} 55^{\prime}\right.$ to $33^{\circ} 01^{\prime} S$; $71^{\circ} 01^{\prime}$ to $71^{\circ} 09^{\prime} \mathrm{W}$ ) and Lago Peñuelas National Reserve ( $33^{\circ} 07^{\prime}$ to $33^{\circ} 13^{\prime} \mathrm{S}$; $71^{\circ} 24^{\prime}$ to $\left.71^{\circ} 34^{\prime} \mathrm{W}\right)$. It is important to indicate that by means of offer of the National Forest Corporation of Chile, the year 2008 extended his surface in near 14 times, going on from 17,095 to 238,216 ha (CONAF, 2008). The altitude ranges from \pm 350 to $\pm 2,222$ masl, and the highest peaks are "El Roble" (2,222 masl) and "La Campana" (1,920 masl). Some sectors of RN Lago Peñuelas contain plantations of exotic species (Pinus radiata D. Don and Eucalyptus globulus Labill.). Another part corresponds to Peñuelas lake, a reservoir covering 1,600 ha which supplies water to the cities of Valparaiso and Viña del Mar, and forms a wetland which is important for migratory,

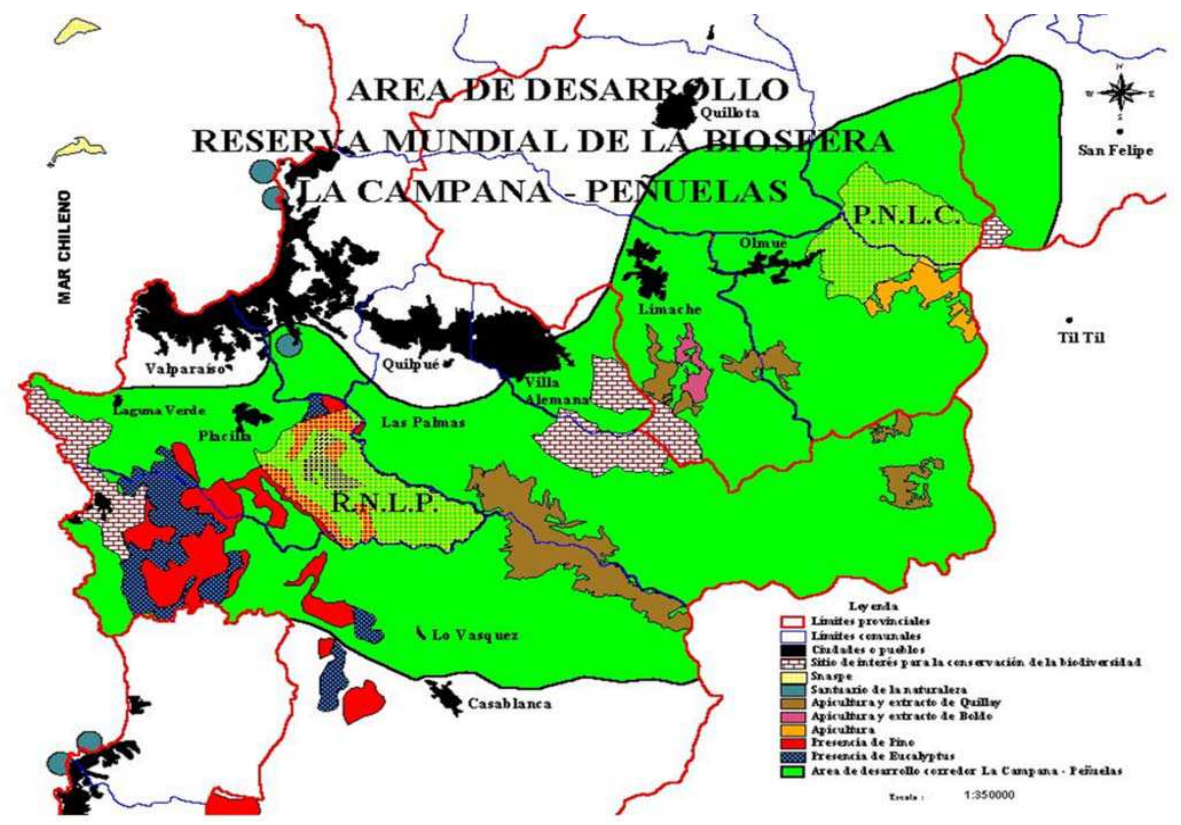

Fig. 1. Map of location of La Campaña-Peñuelas Biosphere Reserve in the Region of Valparaiso, Chile. 
Wealth of Flora and Vegetation

occasional or resident birds; more than 125 species of water, land and shore birds have been recorded in the lake (Strang, 1983) (figure 1, photos 1, 2, 3). The climate of the area is temperate-mediterranean, with sufficient humidity, winter rains and a prolonged dry season. The average annual temperature is $13.5^{\circ} \mathrm{C}$; the average maximum is $17.1^{\circ} \mathrm{C}$ and the average minimum is $9.4^{\circ} \mathrm{C}$; the temperature occasionally falls to $0^{\circ} \mathrm{C}$, with frosts between May and September. Precipitation is seasonal (656 mm/year), from the end of May to August, with a markedly dry summer of six to eight months from October to March (Di Castri \& Hajek, 1976; Luebert \& Pliscoff, 2006).

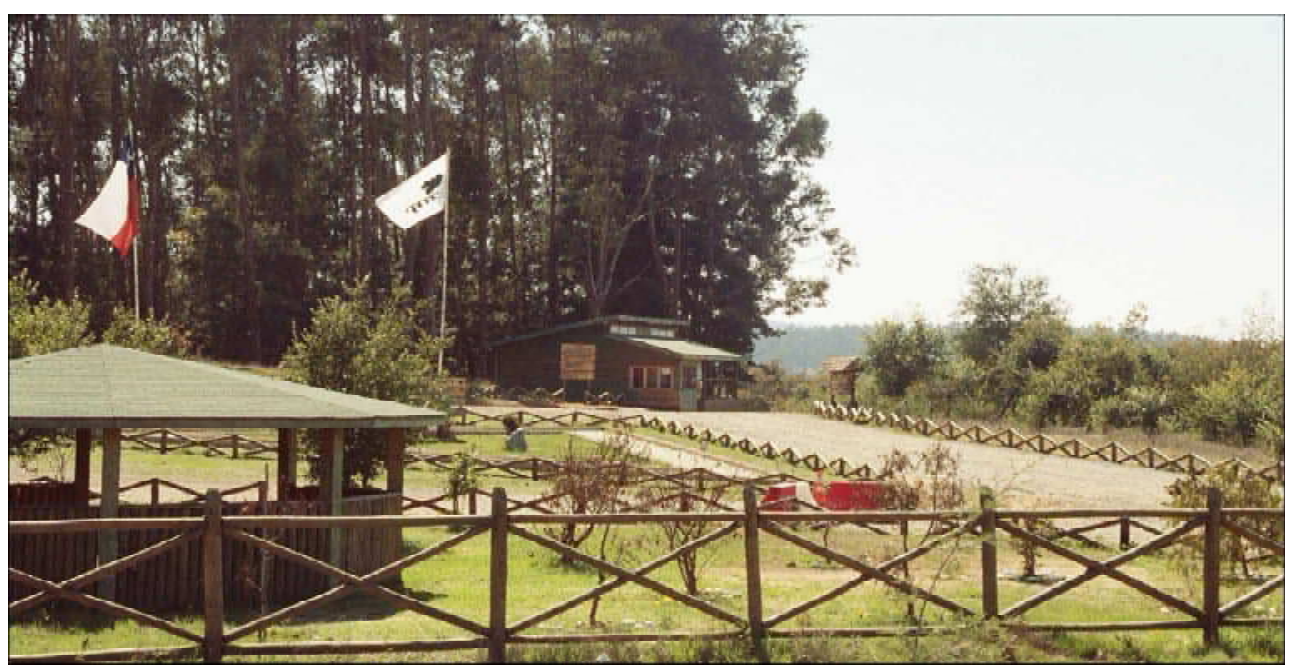

Photo 1. Place of access to the Reserve for the sector of the Peñuelas lake.

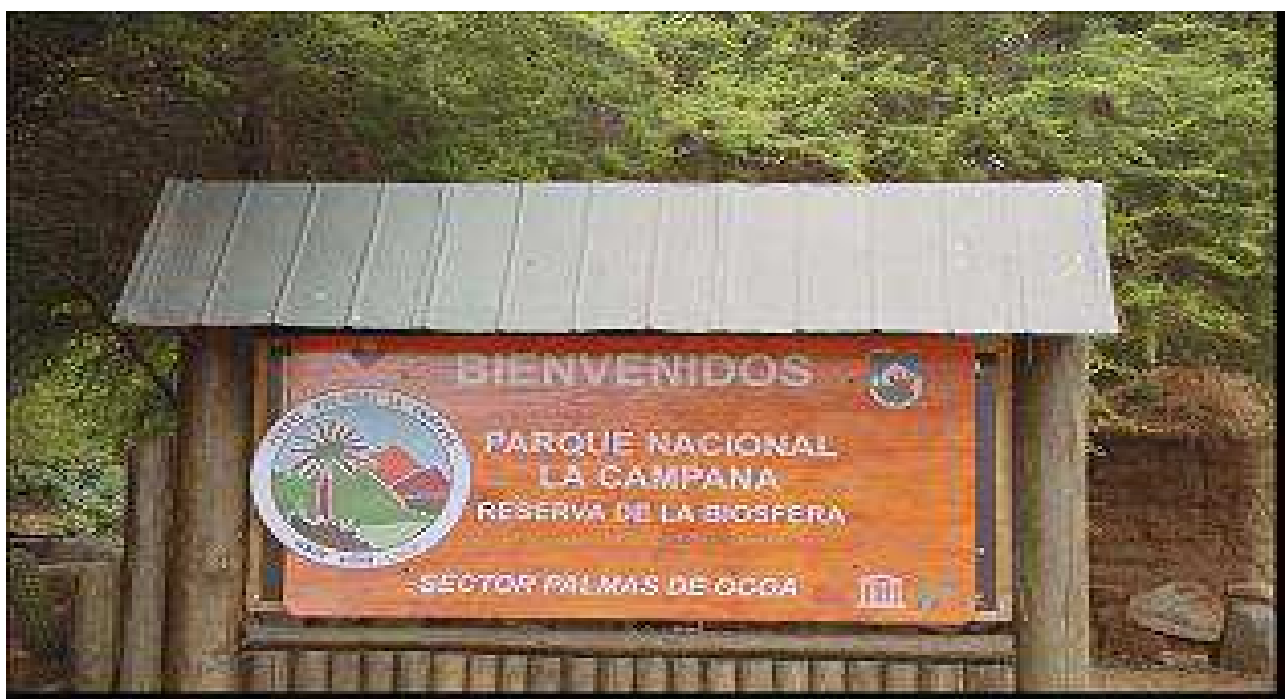

Photo 2. Place of access to the Reserve for the sector of Ocoa's Palms. 


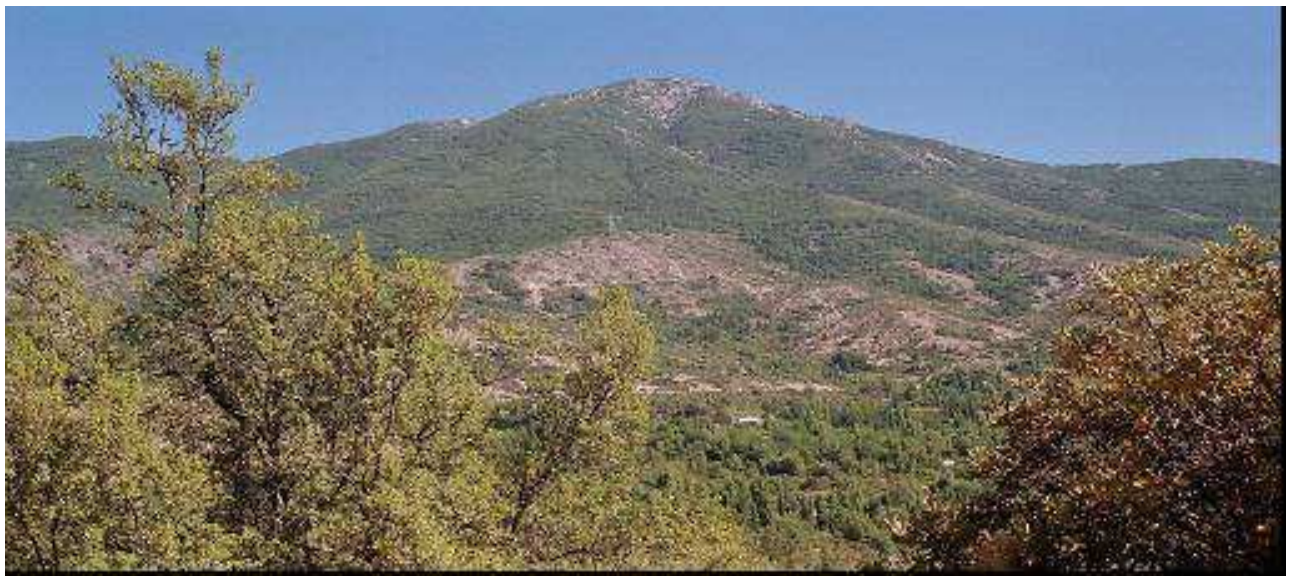

Photo 3. Sight of the Hill the Oak, major summit of La Campana-Peñuelas Biosphere Reserve.

\subsection{Methodology}

The study of the flora and vegetation of the Reserve was carried out by field activities and bibliographic review. Field trips were done in February and November 2001, with intensive collection and 27 phytosociological surveys in nine sampling stations in the Peñuelas National Reserve. The area of each inventory was $4 \mathrm{~m}^{2}$ for herbaceous vegetation, $25 \mathrm{~m}^{2}$ for shrubs and $100 \mathrm{~m}^{2}$ for forest species, within areas greater than the minimum area (Steubing et al., 2002). Aquatic and marsh vegetation were also included on the shores of Peñuelas lake. The phytosociological tables were processed according to the methodology proposed by Braun-Blanquet (1964, 1979), as explained in Ramírez \& Westermeier (1976). The bibliographic review was based principally on the following works: Looser $(1927,1944)$, Rundel \& Weisser (1975), Rodríguez (1979, 1982), ICSA (1980), Villaseñor (1980, 1986), Villaseñor \& Serey (1980-1981), Balduzzi et al. (1981, 1982), Rodríguez \& Calderón (1982), CONAF (1986, 1994), Zöllner et al. (1995), Elórtegui \& Moreira (2002), Novoa et al. (2006), CONAF (2008) and Hauenstein et al. (2009).

The identification, nomenclature and geographical origin of each species was based on Muñoz (1966), Navas (1973, 1976, 1979), Hoffmann (1978, 1991), Marticorena \& Quezada (1985), Matthei (1995), Hoffmann et al. (1998) and Marticorena \& Rodríguez (1995, 2001, 2003, 2005). The International Plant Names Index (IPNI 2011) was used to update the scientific names and abbreviations. Life forms were determined according to the scheme proposed by Ellenberg \& Mueller-Dombois (1966) and the state of conservation of the species was determined considering the proposals of Benoit (1989), updated by a meeting of experts in September 1997 (Baeza et al., 1998; Belmonte et al., 1998; Ravenna et al., 1998), and de Novoa et al. (2006) for the Orchidaceae. The degree of human disturbance of the site was determined on the basis of the proposal of Hauenstein et al. (1988) and the evaluation scale of González (2000), which consider phytogeographic origin (the ratio between native and introduced species), and life forms (Raunkiaer's biological forms) as measurements of this form of disturbance. The result was an inventory of the flora in the study area (table 2), containing all the above elements. 
The vegetation units were determined using the maps produced by CONAF \& CONAMA (1999) and specific cartography provided by CONAF (National Forest Corporation), Valparaiso Region. The definition and nomenclature of the vegetation units followed the proposal of Gajardo (1995). The vegetation units identified in the map for study were subsequently verified on the ground.

\subsection{Results}

Flora. The vascular flora recorded (table 2) included 420 species distributed as: 12 Pteridophytes (3.0\%), 3 Gymnosperms (1.0\%), 290 Dicotyledons (69.0\%) and 115 Monocotyledons (27.0\%) (figure 2). The phytogeographic origin (figure 3) indicates that $49.0 \%$ of the species (207 sp.) are native, $28.0 \%$ (118 sp.) endemic and $23.0 \%$ (95 sp.) introduced. The biological spectrum (life-forms; figure 4) was represented by 122 hemicryptophytes $(29.0 \%), 112$ therophytes $(26.4 \%)$ corresponding to annual and biannual plants, 72 cryptophytes (17.1\%) including hydrophytes and geophytes, 52 nanophanerophytes (shrubs) $(12.4 \%), 38$ phanerophytes (trees) $(9.0 \%), 14$ vines $(3.3 \%), 5$ chamaephytes (low shrubs) (1.4\%), 4 parasites (1.0\%) and only one epiphyte $(0.2 \%)$.

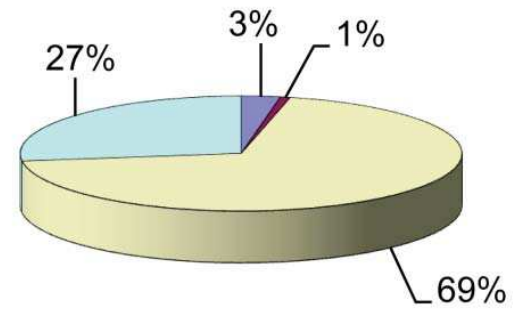

口Pteridophyta

Gymnospermae

口Magnoliopsida

口Liliopsida

Fig. 2. Taxonomic distribution (\%) of the flora in La Campana-Peñuelas Biosphere Reserve, Chile.

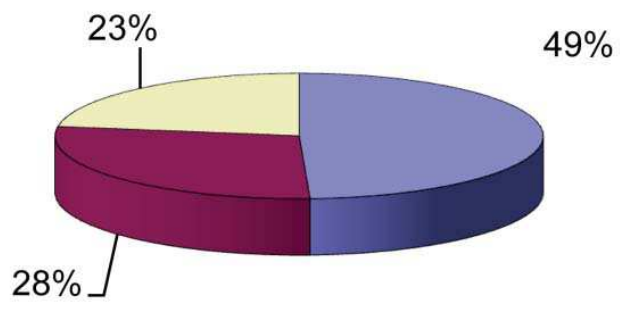

\section{口Native \\ 口Endemic \\ 口Introduced}

Fig. 3. Phytogeographic origin (\%) of the flora in La Campana-Peñuelas Biosphere Reserve, Chile. 


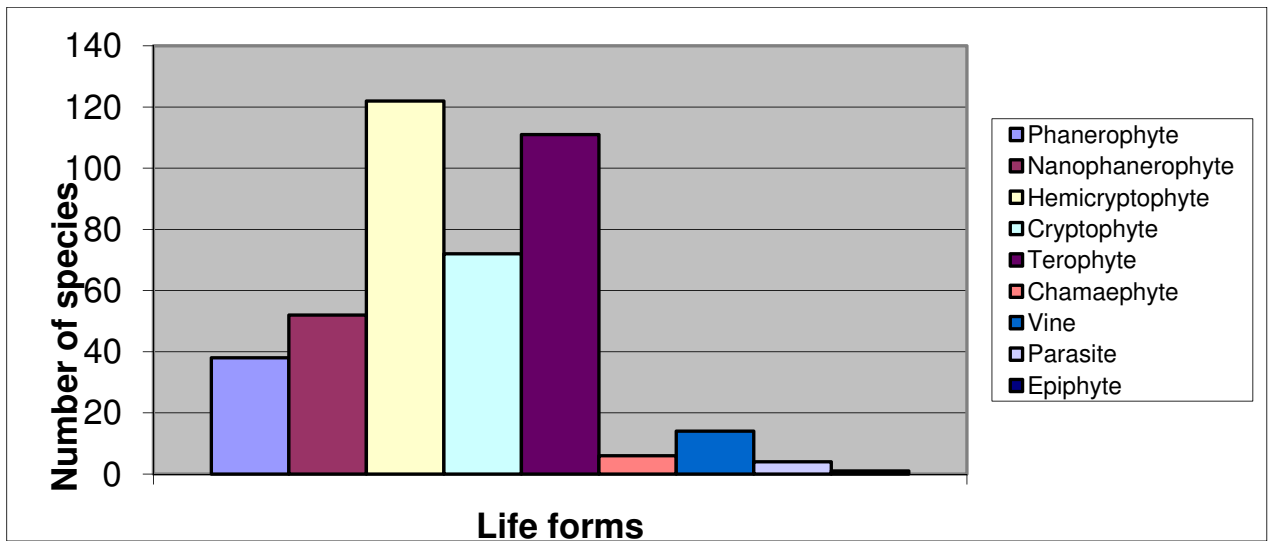

Fig. 4. Biological spectrum (life forms) of the flora in La Campana-Peñuelas Biosphere Reserve, Chile.

The state of conservation of the species (table 1), considering the total mentioned for the area, shows that the majority present no problems, with 18 species $(4.5 \%)$ being identified as suffering from conservation problems. Of these, two are in the "Endangered" category, Beilschmiedia miersii (belloto del norte) and Calydorea xiphioides (tahay); 14 in the "Vulnerable" category, mainly species of bulbs (geophytes) such as Herbertia lahue, Leucocoryne ixioides, L. violacescens and Phycella bicolor; two in the "Rare" category, Alstroemeria garaventae and A. zoellneri; and just one species in the "Insufficiently known" category, Blechnum cordatum, of which a single specimen was recorded in the El Abrevadero sector.

Vegetation. The vegetation in the Reserve includes the following woody communities: sclerophyllous forest, hygrophilous forest, deciduous forest, thorny scrub and mixed sclerophyllous scrub. The herbaceous communities include: dry grassland, wet grassland, reed beds, sedge beds and the aquatic plant community. These communities are characterised as:

1. Peumo and boldo sclerophyllous forest. This is a woody formation typical of the region. This community corresponds to Peumo-Cryptocaryetum albae (Oberdorfer, 1960). Variants can be found with sclerophyllous scrub species (Retanilla trinervia, Gochnatia foliolosa), and one with Chilean palm tree (Jubaea chilensis). The average cover of the arboreal stratum is $70 \%$, shrubs $35 \%$ and herbaceous $25 \%$. The principal arboreal species are: Cryptocarya alba, Peumus boldus, Persea lingue and Dasyphyllum excelsum; shrubs are dominated by: Retanilla trinervia, Schinus latifolia and Chusquea cumingii,; creepers and lianas included: Proustia pyrifolia, Lardizabala funaria and Cissus striata; herbaceous vegetation comprised mainly: Blechnum hastatum, Alonsoa meridionalis, Conyza floribunda and Anagallis arvensis. The altitude ranges of this community is from 350 to 1,000 masl (Elórtegui \& Moreira, 2002; Hauenstein et al., 2009).

2. Quillay and litre sclerophyllous forest. A more strongly xerophytic community than the first category described above, with cover between 40 and $90 \%$. The principal arboreal species are: Cryptocarya alba, Quillaja saponaria and Lithrea caustica; shrubs: Retanilla trinervia, Schinus latifolia, Colliguaja odorifera, Podanthus mitiqui and Escallonia pulverulenta; and herbaceous species include: Adiantum chilense, Solenomelus 
pedunculatus, Vulpia myuros, Alonsoa meridionalis, Conyza floribunda and Anagallis arvensis. The altitude range is from 500 to 1,050 masl. There is also a variant with Jubaea chilensis, in which Aristeguietia salvia and Acacia caven are also present (Elórtegui \& Moreira, 2002; Hauenstein et al., 2009).

\begin{tabular}{|l|l|l|}
\hline Species & EC & Bibliographical source \\
\hline Alstroemeria garaventae & R & Ravenna et al. (1998) \\
\hline Alstroemeria hookeri & V & Ravenna et al. (1998) \\
\hline Alstroemeria zoellneri & R & Ravenna et al. (1998) \\
\hline Beilschmiedia miersii & P & Benoit (1989) \\
\hline Blechnum cordatum & IC & Baeza et al. (1998) \\
\hline Blepharocalyx cruckshanksii & V & Benoit (1989) \\
\hline Calydorea xyphioides & P & Ravenna et al. (1998) \\
\hline Chloraea disoides & V & Ravenna et al. (1998), Novoa et al. (2006) \\
\hline Chloraea heteroglossa & V & Ravenna et al. (1998), Novoa et al. (2006) \\
\hline Conanthera trimaculata & V & Benoit (1989) \\
\hline Eriosyce curvispina & V & Benoit (1989), Belmonte et al. (1998) \\
\hline Herbertia lahue & V & Benoit (1989) \\
\hline Jubaea chilensis & V & Benoit (1989) \\
\hline Leucocoryne ixioides & V & Benoit (1989) \\
\hline Leucocoryne violacescens & V & Benoit (1989) \\
\hline Persea lingue & V & Benoit (1989), \\
\hline Phycella bicolor & V & Benoit (1989) \\
\hline Puya chilensis & V & Benoit (1989) \\
\hline
\end{tabular}

Table 1. Vascular plants with conservation problems of the La Campana-Peñuelas Biosphere Reserve $(\mathrm{EC}=$ condition of conservation, $\mathrm{P}=$ threatened, $\mathrm{R}=$ rare, $\mathrm{V}=$ vulnerable, $\mathrm{IC}=$ insufficiently known).

3. Temo and pitra hydrophilous laurifolious forest. Includes small remnants of forest associated with permanent watercourses and springs, present in the Vega del Alamo sector of RN Peñuelas. These are composed of hygrophilous species such as Drimys winteri, Myrceugenia obtusa, Blepharocalyx cruckshanksii and Luma chequen, and some creepers like Lardizabala biternata and Cissus striata, and correspond to the BlepharocalyoMyrceugenietum exsuccae association (hualve or swamp forest) of myrtaceous plants in the central southern zone of Chile (Ramírez et al. 1996). These forests are included in the Wintero-Nothofagetea phytosociological class defined by Oberdorfer (1960). Other woody species present in this community were: Maytenus boaria and Escallonia revoluta, together with some creepers such as Cissus striata and Lardizabala biternata. The herbaceous stratum is scarce, probably due to the closed canopy, which hinders the penetration of 
light; where present it is represented by Uncinia trichocarpa and ferns like Blechnum hastatum and B. cordatum. This community is found at 270 masl (Hauenstein et al., 2009).

4. Belloto hygrophilous laurifolious forest. This community is characterised by an arboreal stratum dominated by Beilschmiedia miersii, Cryptocarya alba and Dasyphyllum excelsum; there is an abundant shrub stratum dominated by Azara celastrina, Chusquea cumingii, Adenopeltis serrata and an abundance of creepers such as Proustia pyrifolia, Lardizabala funaria and Bomarea salsilla. It is found in low-lying areas, up to 500 masl (Elórtegui \& Moreira, 2002).

5. Canelo hygrophilous laurifolious forest. The arboreal stratum, dominated by Drimys winteri; an abundant shrub stratum, with Otholobium glandulosum, Escallonia myrtoidea, Maytenus boaria and occasionally Salix humboldtiana; and in the herbaceous stratum, Equisetum bogotense. In altered sectors by human activities, cover may be diminished to as little as 30\%. It is found at between 500 and 1,300 masl (Elórtegui \& Moreira, 2002).

6. Deciduous roble forest. This community is characterised by a well differentiated arboreal stratum with Nothofagus macrocarpa and Lomatia hirsuta; a shrub stratum with Azara petiolaris, Ribes punctatum, Schinus montanus, Berberis actinacantha and Aristotelia chilensis; and an herbaceous stratum with, Adiantum sulphureum, Loasa tricolor, Oxalis laxa and Alstroemeria zoellneri, respectively. The cover is from 70 to $100 \%$ and it is found between 1,100 and 1,500 masl. At altitudes above 1,500 masl, a clear diminution may be seen in the tree and shrub cover, constituting a variant with other species such as Schizanthus hookeri, Valeriana lepidota and Senecio anthemidiphyllus (Elórtegui \& Moreira, 2002) (photo 4).

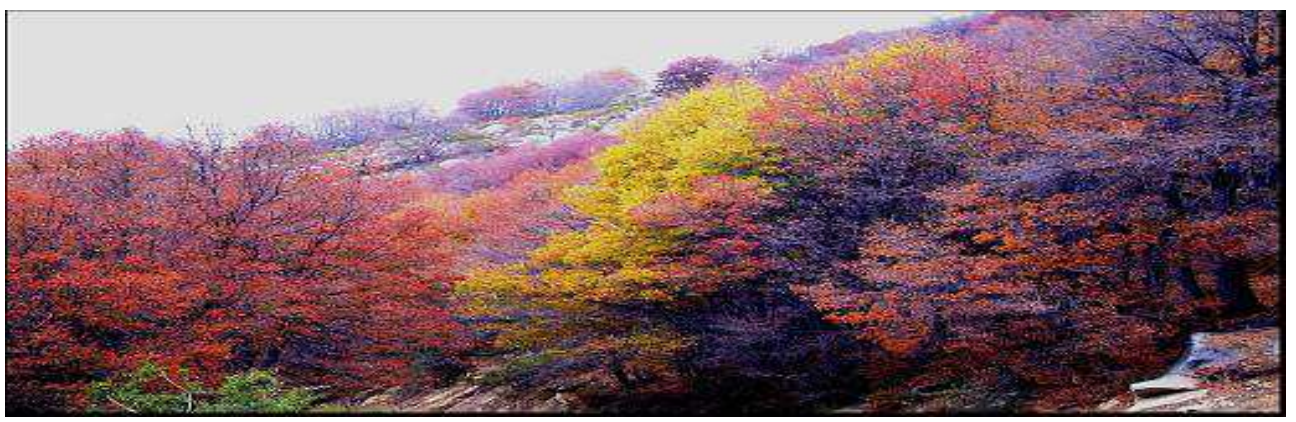

Photo 4. Nothofagus macrocarpa forest in the sector of the Hill the Oak.

7. Espino thorny scrub. The dominant species in the community are espino (Acacia caven $=$ Vachellia caven) and maitén (Maytenus boaria), with average cover of 50\% and $10 \%$ respectively. It is characterised by the presence of a rich herbaceous stratum, especially Agrostis capillaris, Leontodon saxatilis, Avena barbata, Bromus hordeaceus, Briza minor, B. maxima and Rhodophiala advena, with clear predominance of forage graminids. This community is found around Peñuelas lake (Hauenstein et al., 2009) (photo 5).

8. Trevo thorny scrub. A little developed shrub community dominated by Retanilla trinervia, accompanied by shrub forms of Lithrea caustica and Quillaja saponaria, and by Cuscuta chilensis, an abundant, parasitic, herbaceous species. Average cover is above $70 \%$ and the community is found between 400 and 1,000 masl. It forms a variant with abundant presence of Jubaea chilensis, but only in the Ocoa sector (Elórtegui \& Moreira, 2002). 


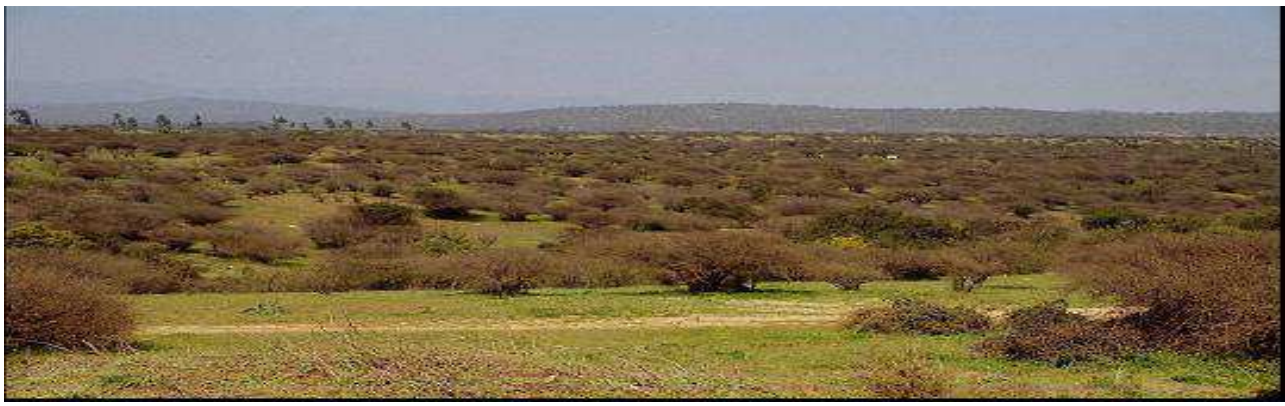

Photo 5. Acacia caven steppe (hawthorn) in sectors near to the Peñuelas lake.

9. Chagual and quisco thorny scrub. An open community of succulents, with a shrub stratum of less than $4 \mathrm{~m}$ height, very diverse, with Puya berteroana, Echinopsis chiloensis, Adesmia arborea, Aristeguietia salvia, Podanthus mitiqui, Retanilla trinervia and occasionally Puya chilensis; the herbaceous stratum is poor, with Helenium aromaticum, Vulpia myuros and Madia sativa. Cover is very variable, between 10 and $80 \%$, but generally not more than $40 \%$. It is found at between 450 and 1,100 masl. It can also form a variant with abundant presence of Jubaea chilensis, but only in the Ocoa sector, with other species Baccharis paniculata and Tristerix corymbosus present (Elórtegui \& Moreira, 2002) (photo 6).

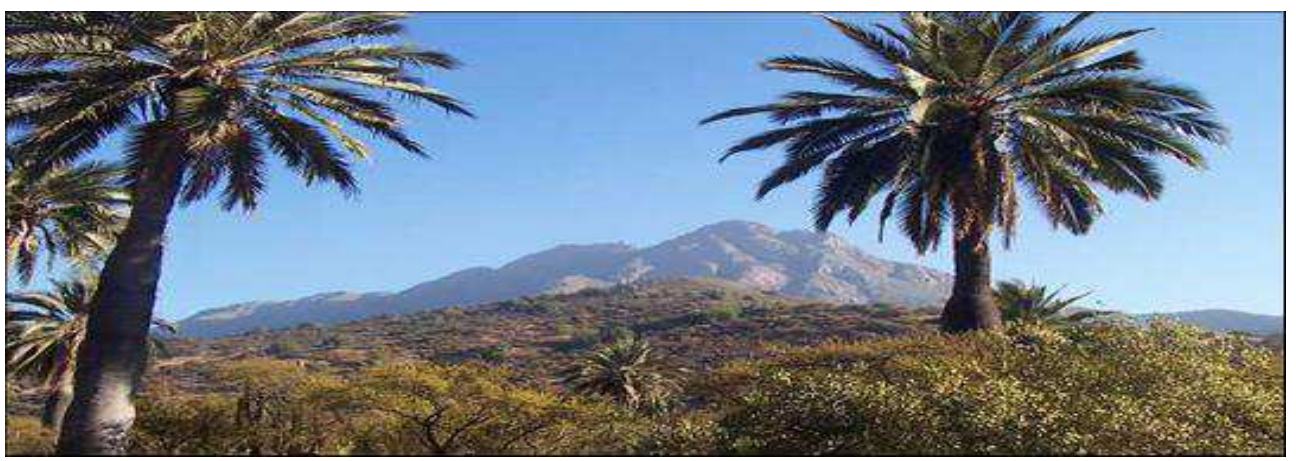

Photo 6. Jubaea chilensis in the sector of Ocoa's Palms.

10. Chagualillo thorny scrub. A low, open shrub community, with two well differentiated strata: higher, with shrubs and succulents of 1-3 $\mathrm{m}$ in height, and lower, $<1 \mathrm{~m}$. The higher stratum is dominated by Puya coerulea, Eryngium paniculatum, Colliguaya odorifera, Retanilla ephedra and Calceolaria polifolia; the lower by Eriosyce curvispina, Tweedia birostrata, Gamochaeta americana, Senecio farinifer and Chorizanthe virgata. Cover varies between 20 and $60 \%$, and the altitude is above 1,100 masl. A variant may also be formed with presence of Jubaea chilensis, with very low cover, the individuals of Chilean palm tree being small and widely dispersed. These communities are found in certain high sectors of Cajón Grande, El Roble and Ocoa, and have cover $\pm 40 \%$ (Elórtegui \& Moreira, 2002).

11. Mira and maicillo thorny scrub. A community with sparse distribution representing situations of sclerophyllous forest with severe disturbance in difficult environments for 
plant life. The dominant species in the shrub stratum are Gochnatia foliolosa, Baccharis rhomboidalis, B. linearis, Satureja gilliesii, Escallonia pulverulenta, Ageratina glechonophylla and Haplopappus velutinus; in the herbaceous stratum, Alstroemeria angustifolia, Solenomelus pedunculatus, Triptilion spinosum, Acaena pinnatifida and Azorella spinosa. The community presents covers of 30 and $50 \%$, at altitudes between 1,000 and 1,300 masl. It can also form a variant with Jubaea chilensis, with very low cover, between 1,000 and 1,200 masl. The differential character of this unit is given by the presence of Vulpia myuros and Baccharis paniculata, indicating a high level of degradation (Elórtegui \& Moreira, 2002).

12. Mixed sclerophyllous scrub. This community is a mixture of species from the acacia steppe with sclerophyllous forest elements, such as Quillaja saponaria, Schinus latifolia, and Cryptocarya alba, together with shrub species, such as Schinus polygama, Baccharis linearis, Berberis actinacantha, Eryngium paniculatum and Satureja gilliesii. It may be characterised as open scrub of espino and romerillo (Baccharis linearis). The dominant woody species are Acacia caven with nearly $20 \%$ cover and B. linearis with $10 \%$; these were followed by Maytenus boaria, Quillaja saponaria and Schinus latifolia; lower canopy comprises Peumus boldus, Lithrea caustica, Escallonia pulverulenta and the creeper Muehlenbeckia hastulata. The herbaceous stratum, with average cover $90 \%$, was represented by the species Agrostis capillaris, Avena barbata, Poa annua, Festuca sp., Bromus hordeaceus, Briza minor and Leontodon saxatilis (Hauenstein et al., 2009).

13. Low altitude neneo scrub. A low, open community of dwarf shrubs (chamaephytes), principally Mulinum spinosum, Chuquiraga oppositifolia, Viviania marifolia, Haplopappus ochagavianus, Ephedra chilensis and a herbaceous stratum formed by Phacelia secunda and Calceolaria campanae. The cover is 10 to $40 \%$; it is found on rocky substrates with variable exposure and gradient, above 1,750 masl, present only at the summits of La Campana and El Roble (Elórtegui \& Moreira, 2002).

14. Dry grassland. The principal floral components of these grasslands were Phyla canescens, Bromus hordeaceus, Agrostis capillaris, Hypochaeris radicata, Gamochaeta coarctata, Leontodon saxatilis, Rumex acetosella and Avena barbata. They correspond to the Bromo-Lolietum community (Oberdorfer, 1960), and are found in the north-east sector of Peñuelas lake, at around 360 masl (Hauenstein et al., 2009).

15-16. Wet grasslands. There are two types. Apart from some of the species of the previous community, the first is distinguished by Mentha pulegium and reeds (Juncus acutus, J. cyperoides, J. pallescens), and corresponds to reedy wet grassland (Juncetum acuti ass. nov.). The second has marked presence of Ludwigia peploides, Cotula coronopifolia, Distichlis spicata and Paspalum dilatatum, corresponding to Polygono-Ludwigietum peploidis (Steubing et al. 1980). Both are found on the northern and southern plains close to Peñuelas lake, although Polygono-Ludwigietum occupies the strip closest to the water (Hauenstein et al., 2009).

17-18. Marsh communities. Two communities of marsh plants were identified, preferably located near the channel which flows into the eastern end of Peñuelas lake. The first, located closer to the water, corresponds to Scirpetum californiae (Ramírez \& Añazco, 1982), the principal component being totora reed (Schoenoplectus californicus), accompanied by Ludwigia peploides and Polygonum hydropiperoides. The second community, found in a continuous strip a little further away from the water, corresponds to Loto-Cyperetum eragrostidae (San Martín et al., 1993), the principal species being Cyperus eragrostis and Carex excelsa (saw-sedges), accompanied by Juncus pallescens 
and J. acutus; it is a perennial, marshy association, typically found in depressions and on the banks of watercourses, associated with totora reeds or the border of swamp forest with temo (Blepharocalyx cruckschanksii) and pitra (Myrceugenia exsucca) (Hauenstein et al., 2002; San Martín et al., 2002). In both communities (reed beds and sedge beds), due to the periodic flooding of the site, hydrophytic life forms dominate absolutely, such as typical helophytes (marsh or swamp plants) and hydrophytes (Hauenstein et al., 2009).

19. Aquatic communities. These communities consist principally of hydrophytic species, particularly Azolla filiculoides, a free-floating pteridophyte, constituting the LemoAzolletum filiculoidis association (Roussine \& Negre, 1952); moreover the high frequency of Hydrocotyle ranunculoides, $H$. modesta and Eleocharis exigua allow the existence of Hydrocotyletum to be inferred (San Martín et al., 1993), however more censuses would be required to confirm this inference. For example, in the least overgrown part of the spring in the El Abrevadero sector of RN Lago Peñuelas, a small body of water is formed which is colonised by aquatic and marsh species such as: Azolla filiculoides, Gunnera tinctoria, Juncus cyperoides, Carex excelsa, Eleocharis exigua, Polygonum hydropiperoides, Hydrocotyle modesta and H. ranunculoides (Hauenstein et al., 2009).

To resume, without considering the variants, 19 plant associations have been described for the Biosphere Reserve.

\subsection{Discussion}

Flora. When the general floral wealth of the area (420 species) is compared with other surveys done in protected wilderness areas in central Chile, we find for the Maule Region: RN Los Bellotos del Melado - 297 species (Arroyo et al., 2000); RN Los Ruiles - 139 species; RN Los Queules - 104 species (Arroyo et al., 2005). For the Metropolitan Region: Monumento Natural El Morado - 300 species (Teillier, 2003); RN Río Clarillo approximately 600 species (Teillier et al., 2005). With the exception of the last, all others consist of considerably fewer species than recorded in the La Campana-Peñuelas Biosphere Reserve, demonstrating the floral wealth of this area.

The biological spectrum shows the predominance of therophytes, hemicryptophytes and cryptophytes over other life forms, which is consistent with the xeric conditions of the site, especially during summer, since therophytes (herbaceous plants with short life cycles, annuals or biannuals) and cryptophytes (geophytes or plants with enduring subterranean organs) represent this type of climate very well and are good environmental indicators. Meanwhile the abundance of hemicryptophytes is indicative of human intervention, since this life form accompanies man and corresponds to plants capable of surviving being trodden on and browsed by domestic animals (Cabrera \& Willink, 1973; Ramírez, 1988; Grigera et al., 1996).

The general phytogeographic origin of the plants in the Reserve indicates that $23 \%$ are introduced species, $49 \%$ native and $28 \%$ endemic. This confirms the high value of this Biosphere Reserve as an area for the conservation of Chile's native and endemic flora. At the same time, when the relatively high percentage of allochthonous species is considered, and compared to the majority of the studies mentioned above where the values for allochthonous species do not exceed $20 \%$, this would indicate a high level of human intervention in the study area. According to Hauenstein et al. (1988) and González (2000), a percentage distribution in which allochthonous plants reach values of between 20 and 30\% 
corresponds to the category of "moderate intervention". This high level of intervention is explained by the large flow of visitors and the presence of domestic animals at certain times of year, leading to the arrival of therophytes and hemicryptophytes which, as mentioned previously, correspond for the most part to fast-growing and strongly invasive plants. To this must be added the different soil structure in some sectors of RN Peñuelas under plantations of exotic species (Pinus radiata, Eucalyptus globulus) and the aggressive colonization by Australian acacias (Acacia dealbata, A. melanoxylon) (ICSA, 1980; CONAF, 1994).

Arroyo et al. (1995) indicate that the high percentage of endemic species is remarkable in all the protected wilderness areas of Chile's central zone, with values over $40 \%$, which rise to $70 \%$ when native plants are included; introduced species thus do not exceed $30 \%$. This is one of the characteristics which highlight the value of these areas as sites where our flora and vegetation units are preserved and protected (Luebert \& Becerra, 1998; Hauenstein et al., 2009).

The high number of monocotyledons in the sector should also be noted, especially the abundance of bulb geophytes, which include the majority of species with conservation problems. It should be born in mind that these bear beautiful, brightly coloured flowers, and are especially important in the Bajo Los Lirios sector (CONAF, 1994, 2008; Hauenstein et al., 2009), where there are very brightly coloured and varied Orchidaceae, the Iridaceae, with lilies of the genera Sisyrinchium and Olsynium, and the tahay (Calydorea xiphioides) an "endangered" species which is very scarce throughout the central zone. There are other more frequent but no less beautiful species, like the lahue (Herbertia lahue), and flowers of the genera Alstroemeria, Phycella, Rhodophiala and Calceolaria, which are of aesthetic importance for recreation and use in gardening (Riedemann \& Aldunate, 2001; Muñoz \& Moreira, 2002).

Vegetation. The total phytosociology of the site consists of 19 plant associations, 6 of which are herbaceous, 7 scrub and 6 forest. With respect to the open espino scrub, also known as "espino or acacia steppe" (Pisano, 1956; CONAF, 1994), it should be made clear that strictly speaking it is not steppe but rather a savannah, as stated by Grau (1992), since the term steppe covers isolated vegetation with denuded surrounding soil and represents cold environments. Savannah on the other hand has isolated trees or thorny shrubs and a rich herbaceous stratum (Cabrera \& Willink, 1973). This herbaceous stratum rich in forage species allows use of this type of community, at certain times of year, for grazing by domestic animals in RN Lago Peñuelas; this activity needs to be reviewed urgently by CONAF, since its effects on the biodiversity of the site are unknown.

The predominance of therophytes and geophytes in the biological spectrum of this plant formation is consistent with the climatic conditions and levels of precipitation in the area, since these life forms present morphological and physiological adaptations to the environmental conditions with extended periods of drought, and they are also important elements as food for wild fauna. The lower percentage of phanerophytes is explained by the low levels of precipitation in the area, and probably also the felling of native woody vegetation in the past. The scarcity of chamaephytes is due to the fact that this life form is adapted to conditions of low temperatures and greater altitude, such as are found only on El Roble and La Campana mountains (Cabrera \& Willink, 1973; Ramírez, 1988; Grigera et al., 1996). 
In the mixed sclerophyllous scrub, the important forms are the sclerophyllous phanerophytes and the therophytes; this also indicates the suitability of this type of plant formation to the climatic conditions of the area. The strong presence of hemicryptophytes indicates human alteration (Hauenstein et al., 1988). Numerous authors have carried out ecophysiological studies on mediterranean scrub species, explaining their ability to adapt to this type of environment, including Mooney \& Kummerow (1971) on the drought response of Flourensia thurifera, Kageneckia oblonga, Lithrea caustica and Proustia cinerea; Montenegro et al. (1979) on the growth dynamic of Colliguaja odorifera, Lithrea caustica, Satureja gilliesii and Retanilla trinervia; Araya \& Avila (1981) on the production of new shoots in scrub species affected by fire; and Avila et al. (1981) on the behaviour of herbaceous stratum species in scrub after a fire.

With respect to sclerophyllous forest, the predominance by phanerophytes and the importance of therophytes and hemicryptophytes are also consistent with the mediterranean climate of the area, since the species present adaptations which enable them to survive intense water stress, e.g. the presence of sclerophyllous leaves (Mooney \& Kummerow, 1971), and the fires which are frequent in the area. For protection against fire, many develop a thick peridermis or a lignotuber, structures which enable them produce new shoots after a disaster (Araya \& Avila, 1981). This community was classified by Oberdorfer (1960) in the class Lithraeo causticae-Cryptocaryetea albae and extends from $31^{\circ}$ South to the limit of temperate territory (Aguilella \& Amigo, 2001). There is no doubt that areas with this type of vegetation have been most affected by human action (Balduzzi et al., 1981, 1982).

At the same time, the remnants of hygrophilous forest, which requires conditions of greater humidity and precipitation, present absolute predominance of phanerophytes and nanophanerophytes (shrubs) over other life forms, indicating that the area would present high levels of rainfall, which is not the case. The explanation of the presence of this forest with hygrophilous characteristics at the site is based on the fact that it grows above a spring located in the Vega del Álamo sector, also known as the "abrevadero de caballos" [horse water-hole], which generates abundant water all year round, maintaining this community with azonal characteristics (Ramírez et al., 1996; Hauenstein et al., 2009).

The dry grassland is characterised by the predominance of hemicryptophytes, indicating strong human action, since these life forms are adapted to survive being trodden on and browsed by animals introduced by man; and of therophytes, indicating drought conditions (Hauenstein et al., 1988; Ramírez, 1988). In the wet grassland on the other hand, cryptophytes and hemicryptophytes predominate.

Reed beds are the most abundant and variable marsh associations in central-southern Chile, colonising marshes and banks of shallow lotic and lentic bodies of water (Ramírez \& Añazco, 1982; Ramírez et al., 1987; San Martín et al., 1993). The same is true of sedge beds, which habitually accompany reed beds, forming a characteristic drier fringe. The principal species, Cyperus eragrostis and Carex excelsa, have sharp-edged leaves, from which their common name of "saw-sedges" derives (Hauenstein et al., 2002, 2005a).

The hydrophyte community corresponds to Lemno-Azolletum, characteristic of eutrophied aquatic environments (Palma et al., 1978); it is mentioned by Ramírez et al. (1987) as very abundant in lakes in Chile's central zone. Likewise, species such as Hydrocotyle modesta and 
$H$. ranunculoides are indicators of organic contamination with nitrogen (Hauenstein et al., 2005b), which would corroborate the high trophic levels of Peñuelas lake; at the same time, this body of water and its associated flora form the habitat for a rich avifauna (Strang, 1983).

In this respect, Arroyo et al. (2005) propose, among other measures, the urgent need to complete inventories of flora of all the protected areas of central Chile; likewise they suggest analysing these areas at the scale of small polygons to evaluate their biological importance and vulnerability, elements which should form the basis for an integrated conservation strategy. Likewise, the findings of Armesto et al. (2002) and Simonetti (2004) are important, regarding the need to increase the number of protected areas, both public and private, to increase the size of existing areas, and to make use of the environment which surrounds them and which has suffered intervention, in order to create interconnectivity zones between them to serve as biological corridors. These units of conservation should consider representation of the different types of vegetation (Luebert \& Becerra, 1998). Another interesting proposal is that of Elórtegui \& Moreira (2002) for La Campana National Park, to zone areas for different types of use. In this context, Simonetti (1995) proposes the need for a model for planning the organization of these protected areas, linking the need to conserve natural resources with their sustainable use, which would be a basic support tool for defining which, where and how possible activities could be carried out, in such a way as would be compatible with conserving biodiversity.

\section{Conclusions}

The study reported here of the La Campana-Peñuelas Biosphere Reserve registered 420 species of vascular plants, of which $49 \%$ are of native origin, $28 \%$ correspond to endemic species and $23 \%$ to introduced species, respectively. Taxonomically, they are divided into 12 Pteridophytes, 3 Gymnosperms, 290 Dicotyledons (Magnoliopsida) and 115 Monocotyledons (Liliopsida), representing a high floral wealth. However, the percentage of allochthonous plants indicates a moderate degree of human disturbance. Eighteen species present conservation problems (2 Endangered, 13 Vulnerable, 2 Rare, 1 Insufficiently known). The vegetation at the site includes the presence of 19 plant communities, six of which are herbaceous, seven shrub and six arboreal. Important sectors exist of standing out in the Reserve such as: Los Lirios sector, which contains a high percentage of bulb species and numerous threatened species; the Vega del Álamo sector as a valuable remnant of hygrophilous forest; and the Ocoa sector due to the important presence of the endemic Chilean palm tree (Jubaea chilensis).

\section{Appendix}

\begin{tabular}{|l|l|l|l|l|l|l|}
\hline Classification / Scientific name & Common name & Family & FV & OF & EC \\
\hline PTERIDOPHYTA & Pdiantaceae & Hc & $\mathrm{N}$ & \\
\hline $\begin{array}{l}\text { Adiantum chilense Kaulf. var. hirsutum } \\
\text { Hook. et Grev. }\end{array}$ & Palito negro & Palito negro & Adiantaceae & Hc & $\mathrm{N}$ & \\
\hline Adiantum excisum Kunze & Palito negro & Adiantaceae & Hc & $\mathrm{N}$ & \\
\hline Adiantum scabrum Kaulf. & Palito negro & Adiantaceae & Hc & $\mathrm{N}$ & \\
\hline Adiantum sulphureum Kaulf. & Palito negro & Adiantaceae & Hc & $\mathrm{N}$ & \\
\hline Adiantum thalictroides Schlecht. & & &
\end{tabular}


Wealth of Flora and Vegetation

in the La Campana-Peñuelas Biosphere Reserve, Valparaiso Region, Chile

\begin{tabular}{|c|c|c|c|c|c|}
\hline Classification / Scientific name & Common name & Family & FV & $\mathrm{OF}$ & EC \\
\hline Azolla filiculoides Lam. & Flor del pato & Azollaceae & $\mathrm{Cr}$ & $\mathrm{N}$ & \\
\hline Blechnum cordatum (Desv.) Hieron & Costilla de vaca & Blechnaceae & $\mathrm{Cr}$ & $\mathrm{N}$ & IC \\
\hline Blechnum hastatum Kaulf. & Palmilla & Blechnaceae & $\mathrm{Hc}$ & $\mathrm{N}$ & \\
\hline Cheilanthes glauca (Cav.) Mett. & s.n. & Adiantaceae & $\mathrm{Hc}$ & $\mathrm{N}$ & \\
\hline Cheilanthes hypoleuca (Kunze) Mett. & Doradilla & Adiantaceae & $\mathrm{Hc}$ & $\mathrm{N}$ & \\
\hline Equisetum bogotense Kunth & Hierba del platero & Equisetaceae & $\mathrm{Hc}$ & $\mathrm{N}$ & \\
\hline Notholaena tomentosa Desv. & s.n. & Adiantaceae & $\mathrm{Hc}$ & $\mathrm{N}$ & \\
\hline \multicolumn{6}{|l|}{ GYMNOSPERMAE } \\
\hline Cupressus macrocarpa Hartw. & \begin{tabular}{|l|} 
Ciprés de \\
Monterrey \\
\end{tabular} & Cupressaceae & $F$ & $\mathrm{I}$ & \\
\hline Ephedra chilensis C.Presl. & Pingo-pingo & Ephedraceae & $\mathrm{Nf}$ & $\mathrm{N}$ & \\
\hline Pinus radiata D.Don & Pino insigne & Pinaceae & $\mathrm{F}$ & $\mathrm{I}$ & \\
\hline \multicolumn{6}{|c|}{ MAGNOLIOPHYTA (ANGIOSPERMAE) } \\
\hline \multicolumn{6}{|l|}{ MAGNOLIOPSIDA (Dicotyledoneae) } \\
\hline Acacia caven (Molina) Molina & Espino & Mimosaceae & $\mathrm{F}$ & $\mathrm{N}$ & \\
\hline Acacia dealbata Link & Aromo & Mimosaceae & $\mathrm{F}$ & $\mathrm{I}$ & \\
\hline Acacia melanoxylon R.Br. & $\begin{array}{l}\text { Aromo } \\
\text { australiano } \\
\end{array}$ & Mimosaceae & $\mathrm{F}$ & $\mathrm{I}$ & \\
\hline Acaena pinnatifida Ruiz et Pav. & cadillo, pimpinela & Rosaceae & $\mathrm{Hc}$ & $\mathrm{N}$ & \\
\hline $\begin{array}{l}\text { Acrisione denticulata (Hook. et Arn.) } \\
\text { B.Nord. }\end{array}$ & Palo de yegua & Asteraceae & $\mathrm{Nf}$ & $\mathrm{E}$ & \\
\hline Adenopeltis colliguaya Bert. & Colliguay & Euphorbiaceae & $\mathrm{Nf}$ & $\mathrm{N}$ & \\
\hline $\begin{array}{l}\text { Adenopeltis serrata (W.T.Aiton) } \\
\text { G.L.Webster }\end{array}$ & Colliguay macho & Euphorbiaceae & $\mathrm{Nf}$ & $\mathrm{E}$ & \\
\hline Adesmia exilis Clos & Paramela & Fabaceae & Hc & E & \\
\hline Adesmia tenella Hook. et Arn. & Trebillo & Fabaceae & $\mathrm{Te}$ & $\mathrm{E}$ & \\
\hline $\begin{array}{l}\text { Ageratina glechonophylla (Less.) R.M.King } \\
\text { et H.Rob. }\end{array}$ & Barbón & Asteraceae & $\mathrm{Nf}$ & $\mathrm{N}$ & \\
\hline Alonsoa meridionalis (L.f.) Kuntze & Ajicillo & Scrophulariaceae & $\mathrm{Te}$ & $\mathrm{N}$ & \\
\hline Amsinckia calycina (Moris) Chater & Ortiguilla & Boraginaceae & Te & $\mathrm{N}$ & \\
\hline Anagallis alternifolia Cav. & s.n. & Primulaceae & $\mathrm{Hc}$ & $\mathrm{N}$ & \\
\hline Anagallis arvensis L. & Pimpinela azul & Primulaceae & $\mathrm{Te}$ & $\mathrm{I}$ & \\
\hline Andeimalva chilensis (Gay) J.A.Tate & s.n. & Malvaceae & $\mathrm{Nf}$ & $\mathrm{E}$ & \\
\hline Anemone decapetala Ard. & Centella & Ranunculaceae & Hc & $\mathrm{N}$ & \\
\hline Anthemis cotula $\mathrm{L}$. & Manzanillón & Asteraceae & $\mathrm{Te}$ & $\mathrm{I}$ & \\
\hline $\begin{array}{l}\text { Aristeguietia salvia (Colla) R.M.King et } \\
\text { H.Rob. }\end{array}$ & Salvia macho & Asteraceae & $\mathrm{Nf}$ & E & \\
\hline Aristolochia chilensis Bridges ex Lindl. & Oreja de zorro & Aristolochiaceae & $\mathrm{Te}$ & E & \\
\hline Aristotelia chilensis (Molina) Stuntz & Maqui & Elaeocarpaceae & $\mathrm{Nf}$ & $\mathrm{N}$ & \\
\hline Armeria maritima (Mill.) Willd. & s.n. & Plumbaginaceae & $\mathrm{Hc}$ & $\mathrm{N}$ & \\
\hline Asteriscium chilense Cham. et Schltdl. & Anicillo & Apiaceae & $\mathrm{Hc}$ & $\mathrm{N}$ & \\
\hline Astragalus berteroanus (Moris) Reiche & Yerba loca & Fabaceae & $\mathrm{Te}$ & $\mathrm{N}$ & \\
\hline Azara celastrina D.Don & Lilén, corcolén & Flacourtiaceae & $\mathrm{F}$ & E & \\
\hline Azara dentata Ruiz et Pav. & Corcolén & Flacourtiaceae & $\mathrm{Nf}$ & $\mathrm{N}$ & \\
\hline
\end{tabular}




\begin{tabular}{|c|c|c|c|c|c|}
\hline Classification / Scientific name & Common name & Family & FV & OF & EC \\
\hline Azara petiolaris (D.Don) I.M.Johnst. & Lilén, Corcolén & Flacourtiaceae & $\mathrm{F}$ & E & \\
\hline Azara serrata Ruiz et Pav. & Lilén, Corcolén & Flacourtiaceae & $\mathrm{F}$ & E & \\
\hline Azorella spinosa (Ruiz et Pav.) Pers. & Yerba santa & Apiaceae & $\mathrm{Hc}$ & $\mathrm{N}$ & \\
\hline Baccharis linearis (Ruiz et Pav.) Pers. & Romerillo & Asteraceae & $\mathrm{Nf}$ & $\mathrm{N}$ & \\
\hline Baccharis macraei Hook. et Arn. & Vautro & Asteraceae & $\mathrm{Nf}$ & $\mathrm{N}$ & \\
\hline Baccharis paniculata DC. & Chilca & Asteraceae & $\mathrm{Nf}$ & $\mathrm{N}$ & \\
\hline Baccharis rhomboidalis Remy & Vautro & Asteraceae & $\mathrm{Nf}$ & $\mathrm{N}$ & \\
\hline Baccharis salicifolia (Ruiz et Pav.) Pers. & Chilca & Asteraceae & $\mathrm{Nf}$ & $\mathrm{N}$ & \\
\hline Bahia ambrosioides Lag. & Manzanilla & Asteraceae & $\mathrm{Nf}$ & $\mathrm{N}$ & \\
\hline Bartsia trixago L. & Belardia & Scrophulariaceae & $\mathrm{Te}$ & $\mathrm{I}$ & \\
\hline Beilschmiedia miersii (Gay) Kosterm. & Belloto del norte & Lauraceae & $\mathrm{F}$ & E & $\mathbf{P}$ \\
\hline Berberis actinacantha Mart. & Michay & Berberidaceae & $\mathrm{Nf}$ & E & \\
\hline $\begin{array}{l}\text { Blepharocalyx cruckshanksii (Hook. et } \\
\text { Arn.) Nied. }\end{array}$ & Temo, Pitra, Picha & Myrtaceae & $\mathrm{F}$ & $\mathrm{N}$ & $\mathbf{V}$ \\
\hline Bowlesia uncinata Colla & Barba de gato & Apiaceae & $\mathrm{Te}$ & $\mathrm{N}$ & \\
\hline $\begin{array}{l}\text { Brassica rapa L. ssp. campestris (L.) } \\
\text { A.R.Clapham }\end{array}$ & Yuyo & Brassicaceae & $\mathrm{Te}$ & $\mathrm{I}$ & \\
\hline Calandrinia compressa Schrad. ex DC. & s.n. & Portulacaceae & $\mathrm{Te}$ & $\mathrm{N}$ & \\
\hline Calandrinia nitida (Ruiz et Pav.) DC. & s.n. & Portulacaceae & Te & $\mathrm{N}$ & \\
\hline $\begin{array}{l}\text { Calceolaria ascendens Lindl. ssp. } \\
\text { glandulifera }\end{array}$ & Topa topa & Scrophulariaceae & Hc & $\mathrm{E}$ & \\
\hline Calceolaria campanae Phil. & Topa topa & Scrophulariaceae & $\mathrm{Hc}$ & E & \\
\hline Calceolaria corymbosa Ruiz et Pav. & $\begin{array}{l}\text { Arguenita del } \\
\text { cerro }\end{array}$ & Scrophulariaceae & Hc & E & \\
\hline Calceolaria dentata Ruiz et Pav. & $\begin{array}{l}\text { Capachito, topa- } \\
\text { top }\end{array}$ & Scrophulariaceae & Hc & E & \\
\hline Calceolaria glandulosa Poepp. ex Benth. & Capachito & Scrophulariaceae & $\mathrm{Hc}$ & $\mathrm{E}$ & \\
\hline Calceolaria meyeniana Phil. & Capachito & Scrophulariaceae & $\mathrm{Hc}$ & E & \\
\hline Calceolaria morisii Walp. & Capachito & Scrophulariaceae & $\mathrm{Hc}$ & $\mathrm{E}$ & \\
\hline Calceolaria oreas Phil. & Capachito & Scrophulariaceae & Hc & E & \\
\hline Calceolaria petioalaris Cav. & $\begin{array}{l}\text { Capachito, topa- } \\
\text { top }\end{array}$ & Scrophulariaceae & Hc & E & \\
\hline Calceolaria polyfolia Hook. & Capachito & Scrophulariaceae & $\mathrm{Nf}$ & E & \\
\hline Calceolaria purpurea Graham & Topa-topa & Scrophulariaceae & $\mathrm{Hc}$ & $\mathrm{E}$ & \\
\hline Calceolaria thyrsiflora Graham & Hierba dulce & Scrophulariaceae & $\mathrm{Hc}$ & $\mathrm{E}$ & \\
\hline Callitriche palustris L. & Huenchecó & Callitrichaceae & $\mathrm{Cr}$ & $\mathrm{N}$ & \\
\hline Camissonia dentata (Cav.) Reiche & s.n. & Onagraceae & $\mathrm{Te}$ & $\mathrm{N}$ & \\
\hline Capsella bursa-pastoris (L.) Medik. & Bolsa de pastor & Brassicaceae & $\mathrm{Te}$ & $\mathrm{I}$ & \\
\hline Cardamine bonariensis Pers. & s.n. & Brassicaceae & $\mathrm{Hc}$ & $\mathrm{N}$ & \\
\hline $\begin{array}{l}\text { Cardionema ramosissimum (Weinm.) } \\
\text { A.Nelson et J.F.Macbr. }\end{array}$ & Dicha & Caryophyllaceae & Hc & $\mathrm{N}$ & \\
\hline Carduus pycnocephalus L. & Cardilla & Asteraceae & Te & $\mathrm{I}$ & \\
\hline Centaurea melitensis L. & Cizaña, abrepuño & Asteraceae & $\mathrm{Te}$ & I & \\
\hline Centaurea solstitialis L. & Cardo amarillo & Asteraceae & $\mathrm{Te}$ & I & \\
\hline
\end{tabular}


Wealth of Flora and Vegetation

in the La Campana-Peñuelas Biosphere Reserve, Valparaiso Region, Chile

\begin{tabular}{|c|c|c|c|c|c|}
\hline Classification / Scientific name & Common name & Family & FV & OF & EC \\
\hline Cerastium fontanum Baumg. & Cerastio & Caryophyllaceae & $\mathrm{Te}$ & $\mathrm{I}$ & \\
\hline Cestrum parqui L'Hér. & Palqui & Solanaceae & $\mathrm{Nf}$ & $\mathrm{N}$ & \\
\hline Chaetanthera linearis Poepp. ex Less. & s.n. & Asteraceae & $\mathrm{Te}$ & $\mathrm{E}$ & \\
\hline $\begin{array}{l}\text { Chaetanthera microphylla (Cass.) Hook. et } \\
\text { Arn. }\end{array}$ & s.n. & Asteraceae & $\mathrm{Te}$ & E & \\
\hline Chenopodium album $\mathrm{L}$. & Quinguilla & Chenopodiaceae & $\mathrm{Te}$ & $\mathrm{I}$ & \\
\hline Chorizante virgata Benth. & Sanguinaria & Polygonaceae & Hc & $\mathrm{E}$ & \\
\hline Chuquiraga oppositifolia D.Don & Hierba blanca & Compositae & $\mathrm{Nf}$ & $\mathrm{N}$ & \\
\hline Cirsium vulgare (Savi) Ten. & Cardo negro & Asteraceae & $\mathrm{Hc}$ & $\mathrm{I}$ & \\
\hline Cissus striata Ruiz et Pav. & Pilpilvoqui & Vitaceae & $\mathrm{Ft}$ & $\mathrm{N}$ & \\
\hline Cistanthe grandiflora Lindl. & Pata de guanaco & Portulacaceae & $\mathrm{Hc}$ & E & \\
\hline Citronella mucronata (Ruiz et Pav.) D.Don & Naranjillo & Icacinaceae & $\mathrm{F}$ & E & \\
\hline $\begin{array}{l}\text { Clarkia tenella (Cav.) F.H.Lewis et } \\
\text { M.E.Lewis }\end{array}$ & Huasita & Onagraceae & Te & $\mathrm{N}$ & \\
\hline Colletia hystrix Clos & Crucero & Rhamnaceae & $\mathrm{Nf}$ & $\mathrm{N}$ & \\
\hline Colliguaja odorifera Molina & Colliguay & Euphorbiaceae & $\mathrm{Nf}$ & E & \\
\hline Conium maculatum L. & Cicuta & Apiaceae & Te & I & \\
\hline Convolvulus arvensis L. & Correhuela & Convolvulaceae & $\mathrm{Hc}$ & $\mathrm{I}$ & \\
\hline Convolvulus chilensis Pers. & $\begin{array}{l}\text { Correhuela } \\
\text { rosada }\end{array}$ & Convolvulaceae & Hc & E & \\
\hline Conyza sumatrensis (Retz.) E.Walker & s.n. & Asteraceae & $\mathrm{Te}$ & $\mathrm{N}$ & \\
\hline Corrigiola squamosa Hook. et Arn. & Hierba del niño & Caryophyllaceae & Hc & $\mathrm{N}$ & \\
\hline $\begin{array}{l}\text { Cotula australis (Sieber ex Spreng.) } \\
\text { Hook.f. }\end{array}$ & s.n. & Asteraceae & Te & $\mathrm{I}$ & \\
\hline Cotula coronopifolia $\mathrm{L}$. & Botón de oro & Asteraceae & Hc & $\mathrm{I}$ & \\
\hline Crassula closiana (Gay) Reiche & Flor de piedra & Crassulaceae & $\mathrm{Te}$ & $\mathrm{N}$ & \\
\hline Crinodendron patagua Molina & Patagua & Elaeocarpaceae & $\mathrm{F}$ & E & \\
\hline Cryptantha aprica (Phil.) Reiche & s.n. & Boraginaceae & $\mathrm{Te}$ & E & \\
\hline Cryptocarya alba (Molina) Looser & Peumo & Lauraceae & $\mathrm{F}$ & $\mathrm{E}$ & \\
\hline Cuscuta chilensis Ker Gawl. & Cabello de ángel & Convolvulaceae & $\mathrm{Fp}$ & $\mathrm{N}$ & \\
\hline Cyclospermum laciniatum (DC.) Constance & Capuchilla & Apiaceae & $\mathrm{Te}$ & $\mathrm{N}$ & \\
\hline Cynara cardunculus L. & Cardo penquero & Asteraceae & Hc & $\mathrm{I}$ & \\
\hline Dasyphyllum excelsum (DC.) Cabrera & Palo santo, Tayú & Compositae & $\mathrm{F}$ & $E$ & \\
\hline Dichondra sericea Sw. & Oreja de ratón & Convolvulaceae & Hc & $\mathrm{N}$ & \\
\hline Diplolepis menziesiiJ.H.Schult. & Voquicillo & Asclepiadaceae & $\mathrm{Ft}$ & $\mathrm{E}$ & \\
\hline Dipsacus sativus (L.) Honck. & Carda & Dipsacaceae & $\mathrm{Te}$ & $\mathrm{N}$ & \\
\hline Drimys winteri J.R.Forst. et G.Forst. & Canelo & Winteraceae & $\mathrm{F}$ & $\mathrm{N}$ & \\
\hline $\begin{array}{l}\text { Echinopsis chiloensis (Colla) Friedrich et } \\
\text { G.D.Rowley }\end{array}$ & Quisco & Cactaceae & $\mathrm{Nf}$ & $\mathrm{E}$ & \\
\hline Eccremocarpus scaber Ruiz et Pav. & Chupa-chupa & Bignoniaceae & $\mathrm{Ft}$ & $\mathrm{N}$ & \\
\hline Erigeron fasciculatus Colla & s.n. & Asteraceae & $\mathrm{Hc}$ & $\mathrm{N}$ & \\
\hline Eriosyce curvispina (Bertero ex Colla) Katt. & Quisquito & Cactaceae & $\mathrm{Nf}$ & E & V \\
\hline Erodium botrys (Cav.) Bertol. & Alfilerillo & Geraniaceae & $\mathrm{Te}$ & $\mathrm{I}$ & \\
\hline Erodium cicutarium (L.) L'Hér. ex Aiton & Alfilerillo & Geraniaceae & $\mathrm{Te}$ & $\mathrm{I}$ & \\
\hline
\end{tabular}




\begin{tabular}{|c|c|c|c|c|c|}
\hline Classification / Scientific name & Common name & Family & FV & $\mathrm{OF}$ & EC \\
\hline Erodium malacoides (L.) L'Hér. ex Aiton & Alfilerillo & Geraniaceae & $\mathrm{Te}$ & $\mathrm{I}$ & \\
\hline Erodium moschatum (L.) L'Hér. ex Aiton & Alfilerillo & Geraniaceae & $\mathrm{Te}$ & $\mathrm{I}$ & \\
\hline $\begin{array}{l}\text { Eryngium paniculatum Cav. et Dombey ex } \\
\text { Delaroche }\end{array}$ & Cardoncillo & Apiaceae & Hc & $\mathrm{N}$ & \\
\hline Escallonia myrtoidea Bertero ex DC. & Lun & Escalloniaceae & $\mathrm{F}$ & $\mathrm{E}$ & \\
\hline Escallonia pulverulenta (Ruiz et Pav.) Pers. & Corontillo & Escalloniaceae & $\mathrm{F}$ & E & \\
\hline Escallonia revoluta (Ruiz et Pav.) Pers. & Lun & Escalloniaceae & $\mathrm{Nf}$ & $\mathrm{N}$ & \\
\hline Escallonia rubra (Ruiz et Pav.) Pers. & Siete camisas & Escalloniaceae & $\mathrm{Nf}$ & $\mathrm{N}$ & \\
\hline Eschscholzia californica Cham. & Dedal de oro & Papaveraceae & $\mathrm{Hc}$ & $\mathrm{I}$ & \\
\hline Eucalyptus globulus Labill. & Eucalipto & Myrtaceae & $\mathrm{F}$ & $\mathrm{I}$ & \\
\hline Euphorbia klotzschii Oudejans & Pichoguilla & Euphorbiaceae & $\mathrm{Te}$ & $\mathrm{N}$ & \\
\hline Euphorbia peplus L. & Pichoga & Euphorbiaceae & $\mathrm{Te}$ & $\mathrm{I}$ & \\
\hline Fabiana imbricata Ruiz et Pav. & Pichi & Solanaceae & $\mathrm{Nf}$ & $\mathrm{N}$ & \\
\hline Facelis retusa (Lam.) Sch. Bip. & s.n. & Asteraceae & $\mathrm{Te}$ & $\mathrm{N}$ & \\
\hline Flourensia thurifera (Molina) DC. & $\begin{array}{l}\text { Maravilla de } \\
\text { campo }\end{array}$ & Asteraceae & $\mathrm{Nf}$ & $\mathrm{E}$ & \\
\hline Fuchsia magellanica Lam. & Chilco & Onagraceae & $\mathrm{Nf}$ & $\mathrm{N}$ & \\
\hline Fumaria capreolata L. & Flor de la culebra & Fumariaceae & Te & $\mathrm{I}$ & \\
\hline Fumaria densiflora DC. & Flor de la culebra & Fumariaceae & $\mathrm{Te}$ & $\mathrm{I}$ & \\
\hline Galium aparine L. & Lengua de gato & Rubiaceae & $\mathrm{Te}$ & $\mathrm{I}$ & \\
\hline Galium hypocarpium (L.) Endl. ex Griseb. & Relbún & Rubiaceae & $\mathrm{Hc}$ & $\mathrm{N}$ & \\
\hline Galium trichocarpum DC. & S.n. & Rubiaceae & $\mathrm{Hc}$ & $\mathrm{E}$ & \\
\hline Gamochaeta coarctata (Willd.) Kerguélen & Nafalium & Asteraceae & $\mathrm{Te}$ & $\mathrm{N}$ & \\
\hline Geranium berteroanum Colla & Core-core & Geraniaceae & Hc & $\mathrm{N}$ & \\
\hline Geranium core-core Steud. & Core-core & Geraniaceae & Hc & $\mathrm{N}$ & \\
\hline Glandularia laciniata (L.) Schnack et Covas & $\begin{array}{l}\text { Hierba del } \\
\text { incornio }\end{array}$ & Verbenaceae & Hc & $\mathrm{N}$ & \\
\hline Gnaphalium cheiranthifolium Lam. & Vira-vira & Asteraceae & $\mathrm{Hc}$ & $\mathrm{N}$ & \\
\hline $\begin{array}{l}\text { Gochnatia foliolosa (D.Don) D.Don ex } \\
\text { Hook. et Arn. }\end{array}$ & Mira-mira & Asteraceae & Hc & $\mathrm{E}$ & \\
\hline Gunnera tinctoria (Molina) Mirb. & Nalca & Gunneraceae & $\mathrm{Cr}$ & $\mathrm{N}$ & \\
\hline Haplopappus linifolius(Phil.) Reiche & S.n. & Asteraceae & $\mathrm{C}$ & $\mathrm{N}$ & \\
\hline Haplopappus ochagavianus Phil. & s.n. & Asteraceae & C & $\mathrm{N}$ & \\
\hline $\begin{array}{l}\text { Haplopappus poeppigianus (Hook. et Arn.) } \\
\text { A.Gray }\end{array}$ & s.n. & Asteraceae & $\mathrm{C}$ & $\mathrm{N}$ & \\
\hline Haplopappus velutinus Remy ssp. illinitus & Buchú & Asteraceae & $\mathrm{C}$ & $\mathrm{N}$ & \\
\hline Helenium aromaticum (Hook.) L.H.Bailey & Manzanilla & Asteraceae & $\mathrm{Te}$ & $\mathrm{N}$ & \\
\hline Hydrocotyle modesta Cham. et Schlecht. & Sombrero de agua & Apiaceae & $\mathrm{Cr}$ & $\mathrm{N}$ & \\
\hline Hydrocotyle ranunculoides L.f. & Sombrero de agua & Apiaceae & $\mathrm{Cr}$ & $\mathrm{N}$ & \\
\hline Hypochaeris glabra L. & $\begin{array}{l}\begin{array}{l}\text { Hierba del } \\
\text { chancho }\end{array} \\
\end{array}$ & Asteraceae & $\mathrm{Te}$ & I & \\
\hline Hypochaeris radicata $\mathrm{L}$. & $\begin{array}{l}\text { Hierba del } \\
\text { chancho }\end{array}$ & Asteraceae & Hc & I & \\
\hline Hypochaeris scorzonerae (DC.) F. Muell. & Escorzonera & Asteraceae & Hc & E & \\
\hline
\end{tabular}


Wealth of Flora and Vegetation

in the La Campana-Peñuelas Biosphere Reserve, Valparaiso Region, Chile

\begin{tabular}{|c|c|c|c|c|c|}
\hline Classification / Scientific name & Common name & Family & FV & OF & EC \\
\hline Kageneckia oblonga Ruiz et Pav. & Bollén & Rosaceae & $\mathrm{F}$ & $\mathrm{E}$ & \\
\hline Lactuca serriola $\mathrm{L}$. & Lechuguilla & Asteraceae & $\mathrm{Te}$ & $\mathrm{I}$ & \\
\hline Lamiun amplexicaule L. & Gallito & Lamiaceae & $\mathrm{Te}$ & $\mathrm{I}$ & \\
\hline Lardizabala biternata Ruiz et Pav. & Cóguil & Lardizabalaceae & $\mathrm{Ft}$ & $\mathrm{N}$ & \\
\hline Lardizabala funaria (Molina) Looser & Cóguil & Lardizabalaceae & $\mathrm{Ft}$ & E & \\
\hline Lathyrus berteroanus Colla & $\begin{array}{l}\text { Clarincillo, } \\
\text { arvejilla }\end{array}$ & Fabaceae & Hc & $\mathrm{N}$ & \\
\hline Lathyrus magellanicus Lam. & $\begin{array}{l}\text { Clarincillo, } \\
\text { arvejilla }\end{array}$ & Fabaceae & Hc & $\mathrm{N}$ & \\
\hline Leontodon saxatilis Lam. & Chinilla & Asteraceae & Hc & $\mathrm{I}$ & \\
\hline Lepidium spicatum Desv. & s.n. & Brassicaceae & $\mathrm{Hc}$ & $\mathrm{N}$ & \\
\hline Leucheria cerberoana Remy & s.n. & Asteraceae & $\mathrm{Te}$ & $\mathrm{N}$ & \\
\hline Linum chamissonis Schied. & Nanco & Linaceae & $\mathrm{Hc}$ & $\mathrm{N}$ & \\
\hline Linum macraei Benth. & Nanco & Linaceae & $\mathrm{Hc}$ & E & \\
\hline Linum usitatissimum L. & Lino, linaza & Linaceae & $\mathrm{Te}$ & $\mathrm{I}$ & \\
\hline Lithrea caustica (Molina) Hook. et Arn. & Litre & Anacardiaceae & $\mathrm{F}$ & $E$ & \\
\hline Loasa tricolor Ker Gawl. & Ortiga caballuna & Loasaceae & Te & $\mathrm{N}$ & \\
\hline Loasa triloba Dombey ex Juss. & Ortiga blanca & Loasaceae & $\mathrm{Te}$ & $\mathrm{N}$ & \\
\hline Lobelia excelsa Bonpl. & Tabaco del diablo & Campanulaceae & $\mathrm{Nf}$ & $E$ & \\
\hline Lobelia polyphyllaHook. et Arn. & Tupa & Campanulaceae & $\mathrm{Nf}$ & E & \\
\hline Logfia gallica (L.) Coss. et Germ. & s.n. & Asteraceae & $\mathrm{Te}$ & $\mathrm{I}$ & \\
\hline Lomatia hirsuta (Lam.) Diels ex J.F.Macbr. & Radal & Proteaceae & F & $\mathrm{N}$ & \\
\hline Lotus subpinnatus Lag. & Porotillo & Fabaceae & $\mathrm{Te}$ & $\mathrm{N}$ & \\
\hline $\begin{array}{l}\text { Ludwigia peploides (Kunth) P.H.Raven } \\
\text { ssp. montevidensis }\end{array}$ & Pasto de la rana & Onagraceae & $\mathrm{Cr}$ & $\mathrm{N}$ & \\
\hline Luma chequen F.Phil. & Chequén, luma & Myrtaceae & $\mathrm{F}$ & $\mathrm{E}$ & \\
\hline Lupinus microcarpus Sims & Arvejilla & Fabaceae & $\mathrm{Te}$ & $\mathrm{N}$ & \\
\hline Lycium chilense Miers ex Bertero & Coralillo & Solanaceae & $\mathrm{Nf}$ & $\mathrm{N}$ & \\
\hline Lythrum hyssopifolia L. & Hierba del toro & Lythraceae & $\mathrm{Te}$ & $\mathrm{I}$ & \\
\hline Madia sativa Molina & Melosa, pegajosa & Asteraceae & $\mathrm{Te}$ & $\mathrm{N}$ & \\
\hline Malesherbia linearifolia (Cav.) Pers. & s.n. & Malesherbiaceae & $\mathrm{Hc}$ & E & \\
\hline Malesherbia sp. & S.n. & Malesherbiaceae & Hc & E & \\
\hline Malva nicaensis All. & Malva & Malvaceae & $\mathrm{Te}$ & $\mathrm{I}$ & \\
\hline Margyricarpus pinnatus (Lam.) Kuntze & Perlilla & Rosaceae & C & $\mathrm{N}$ & \\
\hline Marrubium vulgare $\mathrm{L}$. & Toronjil cuyano & Lamiaceae & $\mathrm{Hc}$ & $\mathrm{I}$ & \\
\hline Matricaria chamomilla L. & Manzanilla & Asteraceae & $\mathrm{Te}$ & $\mathrm{I}$ & \\
\hline Maytenus boaria Molina & Maitén & Celastraceae & $\mathrm{F}$ & $\mathrm{N}$ & \\
\hline Medicago arabica (L.) Huds. & Hualputra & Fabaceae & $\mathrm{Te}$ & $\mathrm{I}$ & \\
\hline Medicago polymorpha L. & Hualputra & Fabaceae & $\mathrm{Te}$ & $\mathrm{I}$ & \\
\hline Melilotus indicus (L.) All. & Trevillo & Fabaceae & $\mathrm{Te}$ & $\mathrm{I}$ & \\
\hline Mentha pulegium L. & Poleo & Lamiaceae & $\mathrm{Hc}$ & $\mathrm{I}$ & \\
\hline Microseris pygmaea D.Don & s.n. & Asteraceae & $\mathrm{Te}$ & $\mathrm{N}$ & \\
\hline Misodendrum linearifolium DC. & Injerto & Misodendraceae & $\mathrm{Fp}$ & $\mathrm{N}$ & \\
\hline Monnina sp. & s.n. & Polygalaceae & $\mathrm{Nf}$ & $\mathrm{N}$ & \\
\hline
\end{tabular}




\begin{tabular}{|c|c|c|c|c|c|}
\hline Classification / Scientific name & Common name & Family & FV & $\mathrm{OF}$ & EC \\
\hline Muehlenbeckia hastulata (Sm.) I.M.Johnst. & Voqui negro & Polygonaceae & $\mathrm{F}$ & $\mathrm{N}$ & \\
\hline Mulinum spinosum (Cav.) Pers. & Neneo & Umbelliferae & $\mathrm{Nf}$ & $\mathrm{N}$ & \\
\hline Mutisia acerosa Poepp. ex Less. & Romerillo & Asteraceae & $\mathrm{Nf}$ & $\mathrm{N}$ & \\
\hline Mutisia ilicifolia Cav. & Clavel del aire & Asteraceae & $\mathrm{Ft}$ & $\mathrm{E}$ & \\
\hline Mutisia latifolia D.Don & Clavel del campo & Asteraceae & $\mathrm{Ft}$ & E & \\
\hline Mutisia rosea Poepp. ex Less. & Clavel del campo & Asteraceae & $\mathrm{Ft}$ & $\mathrm{E}$ & \\
\hline Mutisia subulata Ruiz et Pav. & Hierba del jote & Asteraceae & $\mathrm{Ft}$ & $\mathrm{N}$ & \\
\hline Myrceugenia exsucca (DC.) O.Berg & Pitra, petra & Myrtaceae & $\mathrm{F}$ & $\mathrm{N}$ & \\
\hline Myrceugenia obtusa (DC.) O.Berg & Arrayán, rarán & Myrtaceae & $\mathrm{F}$ & $\mathrm{E}$ & \\
\hline Myriophyllum aquaticum (Vell.) Verdc. & Pinito de agua & Haloragaceae & $\mathrm{Cr}$ & $\mathrm{N}$ & \\
\hline Nasturtium officinale R.Br. & Berro & Brassicaceae & $\mathrm{Hc}$ & $\mathrm{I}$ & \\
\hline Nicotiana acuminata (Graham) Hook. & Tabaco del campo & Solanaceae & $\mathrm{Te}$ & $\mathrm{N}$ & \\
\hline $\begin{array}{l}\text { Nothofagus macrocarpa(A.DC.) } \\
\text { F.M.Vázquez et R.A.Rodr. }\end{array}$ & Roble & Nothofagaceae & $\mathrm{F}$ & $\mathrm{E}$ & \\
\hline Oenothera acaulis Cav. & Diego de la noche & Onagraceae & $\mathrm{Hc}$ & $\mathrm{N}$ & \\
\hline Oenothera affinis Spach & Diego de la noche & Onagraceae & Te & $\mathrm{N}$ & \\
\hline Otholobium glandulosum (L.) J.W.Grimes & Culén & Fabaceae & $\mathrm{Nf}$ & $\mathrm{N}$ & \\
\hline Oxalis articulata Savign. & Culle & Oxalidaceae & $\mathrm{Cr}$ & $\mathrm{N}$ & \\
\hline Oxalis corniculata $\mathrm{L}$. & Vinagrillo & Oxalidaceae & $\mathrm{Hc}$ & $\mathrm{I}$ & \\
\hline Oxalis laxa Hook. et Arn. & Culle & Oxalidaceae & Te & $\mathrm{N}$ & \\
\hline Oxalis megalorrhiza Jacq. & Vinagrillo & Oxalidaceae & $\mathrm{Hc}$ & $\mathrm{N}$ & \\
\hline Oxalis micrantha Bertero ex Colla & Vinagrillo & Oxalidaceae & $\mathrm{Hc}$ & $\mathrm{N}$ & \\
\hline Oxalis perdicaria (Molina) Bertero & Flor de la perdiz & Oxalidaceae & $\mathrm{Cr}$ & $\mathrm{N}$ & \\
\hline Oxalis rosea Jacq. & Culle, vinagrillo & Oxalidaceae & $\mathrm{Te}$ & $\mathrm{E}$ & \\
\hline Persea lingue Nees. & Lingue & Lauraceae & $\mathrm{F}$ & $\mathrm{N}$ & $\mathbf{V}$ \\
\hline Peumus boldus Molina & Boldo & Monimiaceae & $F$ & E & \\
\hline Phacelia circinata Jacq. & Té de burro & Hydrophyllaceae & $\mathrm{Hc}$ & $\mathrm{N}$ & \\
\hline Phacelia secunda J.F.Gmel. & Té de burro & Hydrophyllaceae & $\mathrm{Hc}$ & $\mathrm{N}$ & \\
\hline Phyla canescens (Kunth) Greene & Hierba de la Virgen & Verbenaceae & $\mathrm{Hc}$ & $\mathrm{N}$ & \\
\hline Plagiobothrys procumbens A.Gray & s.n. & Boraginaceae & $\mathrm{Te}$ & $\mathrm{N}$ & \\
\hline Plantago hispidula Ruiz et Pav. & s.n. & Plantaginaceae & Te & $\mathrm{N}$ & \\
\hline Plantago lanceolata L. & Siete venas & Plantaginaceae & $\mathrm{Hc}$ & $\mathrm{I}$ & \\
\hline Podanthus mitiqui Lindl. & Mitique & Asteraceae & $\mathrm{Nf}$ & E & \\
\hline Polygonum hydropiperoides Michx. & Duraznillo & Polygonaceae & $\mathrm{Hc}$ & $\mathrm{N}$ & \\
\hline Polygonum persicaria L. & Duraznillo & Polygonaceae & Te & $\mathrm{I}$ & \\
\hline Populus deltoides Bartram ex Marshall & Alamo americano & Salicaceae & $\mathrm{F}$ & $\mathrm{I}$ & \\
\hline Populus nigra L. & Alamo negro & Salicaceae & $\mathrm{F}$ & $\mathrm{I}$ & \\
\hline Porliera chilensis Johnst. & Guayacán & Zygophyllaceae & $\mathrm{Nf}$ & $\mathrm{E}$ & \\
\hline Proustia pyrifolia DC. & Voqui blanco & Asteraceae & $\mathrm{Ft}$ & E & \\
\hline Quillaja saponaria Molina & Quillay & Rosaceae & $\mathrm{F}$ & E & \\
\hline Quinchamalium chilense Molina & Quinchamalí & Santalaceae & $\mathrm{Hc}$ & $\mathrm{N}$ & \\
\hline Ranunculus chilensis DC. & Ranúnculo & Ranunculaceae & Te & $\mathrm{N}$ & \\
\hline Ranunculus muricatus L. & Centella, huante & Ranunculaceae & $\mathrm{Hc}$ & $\mathrm{I}$ & \\
\hline
\end{tabular}


Wealth of Flora and Vegetation

in the La Campana-Peñuelas Biosphere Reserve, Valparaiso Region, Chile

\begin{tabular}{|c|c|c|c|c|c|}
\hline Classification / Scientific name & Common name & Family & FV & $\mathrm{OF}$ & EC \\
\hline Rapistrum rugosum (L.) All. & Falso yuyo & Brassicaceae & $\mathrm{Te}$ & $\mathrm{I}$ & \\
\hline Retanilla ephedra(Vent.) Brongn. & Retamilla & Rhamnaceae & $\mathrm{Nf}$ & E & \\
\hline $\begin{array}{l}\text { Retanilla trinervia (Guillies et Hook.) } \\
\text { Hook. et Arn. }\end{array}$ & Trevo, tebo & Rhamnaceae & $\mathrm{Nf}$ & E & \\
\hline Rhaphithamnus spinosus (Juss.) Moldenke & Arrayán macho & Verbenaceae & $\mathrm{F}$ & $\mathrm{N}$ & \\
\hline Ribes punctatum Ruiz et Pav. & Zarzaparrilla & Grossulariaceae & $\mathrm{Nf}$ & $\mathrm{N}$ & \\
\hline Robinia pseudoacacia L. & Falsa acacia & Fabaceae & $\mathrm{F}$ & $\mathrm{I}$ & \\
\hline Rosa moschata Herrm. & Mosqueta, coral & Rosaceae & $\mathrm{Nf}$ & I & \\
\hline Rubus ulmifolius Schott & Zarzamora, mora & Rosaceae & $\mathrm{Nf}$ & $\mathrm{I}$ & \\
\hline Rumex acetosella $\mathrm{L}$. & Vinagrillo & Polygonaceae & Hc & $\mathrm{I}$ & \\
\hline Rumex conglomeratus Murray & Romaza & Polygonaceae & $\mathrm{Hc}$ & $\mathrm{I}$ & \\
\hline Rumex crispus L. & Romaza & Polygonaceae & $\mathrm{Hc}$ & $\mathrm{I}$ & \\
\hline Rumex pulcher L. & Romaza & Polygonaceae & $\mathrm{Hc}$ & I & \\
\hline Sagina apetala Ard. & s.n. & Caryophyllaceae & $\mathrm{Te}$ & I & \\
\hline Salix babylonica L. & Sauce llorón & Salicaceae & $\mathrm{F}$ & $\mathrm{I}$ & \\
\hline Salix humboldtiana Willd. & Sauce amargo & Salicaceae & $\mathrm{F}$ & $\mathrm{N}$ & \\
\hline Sanicula crassicaulis Poepp. ex DC. & Pata de leon & Apiaceae & Hc & $\mathrm{N}$ & \\
\hline Satureja gilliesii (Graham) Briq. & Menta de árbol & Lamiaceae & $\mathrm{Nf}$ & $\mathrm{E}$ & \\
\hline Schinus latifolia (Gillies ex Lindl.) Engler & Molle & Anacardiaceae & $\mathrm{F}$ & E & \\
\hline Schinus montana (Phil.) Engler & Litrecillo & Anacardiaceae & $\mathrm{F}$ & E & \\
\hline Schinus polygama (Cav.) Cabrera & Huingán, borocoi & Anacardiaceae & $\mathrm{Nf}$ & $\mathrm{N}$ & \\
\hline Schizanthus hookeri Gillies ex Graham & Mariposita & Solanaceae & $\mathrm{Hc}$ & $\mathrm{N}$ & \\
\hline Schizanthus litoralis Phil. & $\begin{array}{l}\text { Pajarito, } \\
\text { mariposita }\end{array}$ & Solanaceae & $\mathrm{Te}$ & $\mathrm{E}$ & \\
\hline Schizanthus pinnatus Ruiz et Pav. & Mariposita & Solanaceae & $\mathrm{Te}$ & $E$ & \\
\hline Schizanthus tricolor Grau et E.Gronbach & Mariposita & Solanaceae & $\mathrm{Te}$ & $\mathrm{N}$ & \\
\hline Senecio adenotrichius DC. & s.n. & Asteraceae & $\mathrm{Hc}$ & $\mathrm{N}$ & \\
\hline Senecio anthemidiphyllus Remy & Senecio & Asteraceae & $\mathrm{Nf}$ & $\mathrm{E}$ & \\
\hline Senecio farinifer Hook. et Arn. & Senecio & Asteraceae & $\mathrm{Nf}$ & $\mathrm{E}$ & \\
\hline Senecio aff. macratus Kunze & Senecio & Asteraceae & $\mathrm{Nf}$ & $\mathrm{N}$ & \\
\hline $\begin{array}{l}\text { Senna candolleana (Vogel) H.S.Irwin et } \\
\text { Barneby }\end{array}$ & Quebracho & Caesalpiniaceae & $\mathrm{F}$ & $\mathrm{N}$ & \\
\hline Silene gallica L. & Calabacillo & Caryophyllaceae & $\mathrm{Te}$ & $\mathrm{I}$ & \\
\hline Silybum marianum (L.) Gaertn. & Cardo blanco & Asteraceae & $\mathrm{Te}$ & $\mathrm{I}$ & \\
\hline Solanum furcatum Dunal ex Poir. & Yerba mora & Solanaceae & $\mathrm{Te}$ & $\mathrm{N}$ & \\
\hline Solanum tomatillo (J.Remy) F.Phil. & Tomatillo & Solanaceae & $\mathrm{Te}$ & $\mathrm{N}$ & \\
\hline Soliva sessilis Ruiz et Pav. & Dicha & Asteraceae & $\mathrm{Te}$ & $\mathrm{N}$ & \\
\hline Sonchus asper (L.) Hill. & Nilhue & Asteraceae & $\mathrm{Te}$ & $\mathrm{I}$ & \\
\hline Sonchus oleraceus L. & Nilhue & Asteraceae & $\mathrm{Te}$ & $\mathrm{I}$ & \\
\hline Sophora macrocarpa Sm. & Mayu & Fabaceae & $\mathrm{F}$ & E & \\
\hline Sphacele salviae (Lindl.) Briq. & Salvia & Lamiaceae & $\mathrm{Nf}$ & E & \\
\hline Spergularia media (L.) C.Presl ex Griseb. & Tiqui-tiqui & Caryophyllaceae & $\mathrm{Te}$ & $\mathrm{I}$ & \\
\hline Stachys albicaulis Lindl. & $\begin{array}{l}\text { Hierba Santa } \\
\text { Rosa }\end{array}$ & Lamiaceae & Hc & $\mathrm{E}$ & \\
\hline
\end{tabular}




\begin{tabular}{|c|c|c|c|c|c|}
\hline Classification / Scientific name & Common name & Family & FV & OF & EC \\
\hline Stachys grandidentata Lindl. & Toronjilcillo & Lamiaceae & Hc & E & \\
\hline Stellaria chilensis Pedersen & Quilloi-quilloi & Caryophyllaceae & Hc & $\mathrm{N}$ & \\
\hline Stellaria media (L.) Cirillo & Quilloi-quilloi & Caryophyllaceae & $\mathrm{Te}$ & $\mathrm{I}$ & \\
\hline Stenandrium dulce (Cav.) Nees & $\begin{array}{l}\text { Hierba de la } \\
\text { piñada }\end{array}$ & Acanthaceae & Hc & $\mathrm{N}$ & \\
\hline Teucrium bicolor $\mathrm{Sm}$. & Oreganillo & Lamiaceae & $\mathrm{Nf}$ & $\mathrm{E}$ & \\
\hline Torilis nodosa (L.) Gaertn. & s.n. & Apiaceae & $\mathrm{Te}$ & $\mathrm{I}$ & \\
\hline Trifolium dubium Sibth. & Trebillo & Fabaceae & $\mathrm{Te}$ & $\mathrm{I}$ & \\
\hline Trifolium polymorphum Poir. & Trébol & Fabaceae & $\mathrm{Hc}$ & $\mathrm{N}$ & \\
\hline Trifolium subterraneum L. & $\begin{array}{l}\text { Trébol } \\
\text { subterráneo }\end{array}$ & Fabaceae & $\mathrm{Cr}$ & $\mathrm{I}$ & \\
\hline Triptilion spinosum Ruiz et Pav. & Siempre viva & Asteraceae & $\mathrm{Hc}$ & $\mathrm{N}$ & \\
\hline $\begin{array}{l}\text { Tristerix aphyllus (Miers ex DC.) Tiegh. ex } \\
\text { Barlow et Wiens }\end{array}$ & $\begin{array}{l}\text { Quintral del } \\
\text { quisco }\end{array}$ & Loranthaceae & Fp & $\mathrm{E}$ & \\
\hline Tristerix corymbosus (L.) Kuijt & Quintral del álamo & Loranthaceae & $\mathrm{Fp}$ & $\mathrm{N}$ & \\
\hline Tropaeolum azureum Miers. & Violeta del campo & Tropaeolaceae & $\mathrm{Ft}$ & E & \\
\hline Tropaeolum ciliatum Ruiz et Pav. & Pajarito & Tropaeolaceae & $\mathrm{Ft}$ & $\mathrm{E}$ & \\
\hline Tropaeolum tricolor Sweet & $\begin{array}{l}\text { Soldadito, } \\
\text { relicario }\end{array}$ & Tropaeolaceae & $\mathrm{Ft}$ & $\mathrm{E}$ & \\
\hline $\begin{array}{l}\text { Tweedia birostrata (Hook. et Arn.) Hook. } \\
\text { et Arn. }\end{array}$ & Zahumerio & Asclepiadaceae & $\mathrm{Ft}$ & $\mathrm{E}$ & \\
\hline Urtica urens L. & Ortiga & Urticaceae & $\mathrm{Te}$ & $\mathrm{I}$ & \\
\hline Valeriana lepidota Clos & Valeriana & Valerianaceae & $\mathrm{Cr}$ & $\mathrm{E}$ & \\
\hline Valeriana verticillata Clos & Valeriana & Valerianaceae & Hc & $\mathrm{N}$ & \\
\hline Verbascum virgatum Stokes & Raspa la choica & Scrophulariaceae & $\mathrm{Te}$ & $\mathrm{I}$ & \\
\hline Verbena bonariensis L. & Verbena & Verbenaceae & $\mathrm{Hc}$ & $\mathrm{N}$ & \\
\hline Veronica anagallis-aquatica L. & No me olvides & Scrophulariaceae & $\mathrm{Cr}$ & $\mathrm{I}$ & \\
\hline Veronica arvensis L. & Verónica & Scrophulariaceae & $\mathrm{Te}$ & $\mathrm{I}$ & \\
\hline Vicia magnifolia Clos & Arvejilla & Fabaceae & Te & $\mathrm{N}$ & \\
\hline Vicia mucronata Clos & Arvejilla & Fabaceae & $\mathrm{Te}$ & $\mathrm{N}$ & \\
\hline Vicia nigricans Hook. et Arn. & Arvejilla & Fabaceae & $\mathrm{Te}$ & $\mathrm{N}$ & \\
\hline Vicia sativa $\mathrm{L}$ & $\begin{array}{l}\text { Arvejilla, } \\
\text { clarincillo }\end{array}$ & Fabaceae & $\mathrm{Te}$ & $\mathrm{I}$ & \\
\hline Viola sp. & Violeta del campo & Violaceae & $\mathrm{Te}$ & $\mathrm{N}$ & \\
\hline Viviania marifolia Cav. & Te de burro & Vivianiaceae & $\mathrm{Nf}$ & $\mathrm{N}$ & \\
\hline \multicolumn{6}{|l|}{ LILIOPSIDA (Monocotyledoneae) } \\
\hline Agrostis capillaris L. & Chépica & Poaceae & $\mathrm{Hc}$ & $\mathrm{I}$ & \\
\hline Aira caryophyllea L. & s.n. & Poaceae & $\mathrm{Te}$ & I & \\
\hline Alisma plantago-aquatica L. & Llantén de agua & Alismataceae & $\mathrm{Cr}$ & $\mathrm{I}$ & \\
\hline Alstroemeria angustifolia Herb. & Lirio del campo & Alstroemeriaceae & $\mathrm{Cr}$ & E & \\
\hline Alstroemeria garaventae Ehr.Bayer & Lirio del campo & Alstroemeriaceae & $\mathrm{Cr}$ & E & $\mathbf{R}$ \\
\hline Alstroemeria hookeri Lodd. ssp. recumbens & Lirio del campo & Alstroemeriaceae & $\mathrm{Cr}$ & $\mathrm{N}$ & $\mathbf{V}$ \\
\hline Alstroemeria ligtu L. ssp. simsii & Lirio del campo & Alstroemeriaceae & $\mathrm{Cr}$ & $\mathrm{E}$ & \\
\hline Alstroemeria pulchra Sims ssp. pulchra & Lirio del campo & Alstroemeriaceae & $\mathrm{Cr}$ & E & \\
\hline
\end{tabular}


Wealth of Flora and Vegetation

in the La Campana-Peñuelas Biosphere Reserve, Valparaiso Region, Chile

\begin{tabular}{|c|c|c|c|c|c|}
\hline Classification / Scientific name & Common name & Family & FV & OF & EC \\
\hline Alstroemeria revoluta Ruiz et Pav. & Lirio del campo & Alstroemeriaceae & $\mathrm{Cr}$ & $\mathrm{E}$ & \\
\hline Alstroemeria zoellneri Ehr.Bayer & Lirio del campo & Alstroemeriaceae & $\mathrm{Cr}$ & E & $\mathbf{R}$ \\
\hline Avena barbata Pott ex Link & Teatina & Poaceae & $\mathrm{Te}$ & $\mathrm{I}$ & \\
\hline Bipinnula mystacina Lindl. & Orquídea & Orchidaceae & $\mathrm{Cr}$ & E & \\
\hline Bipinnula plumosa Lindl. & Orquídea & Orchidaceae & $\mathrm{Cr}$ & $\mathrm{E}$ & \\
\hline Bomarea salsilla Mirb. & Bomarea & Alstroemeriaceae & $\mathrm{Ft}$ & $\mathrm{N}$ & \\
\hline Brachystele unilateris (Poir.) Schltr. & Orquídea & Orchidaceae & $\mathrm{Cr}$ & $\mathrm{E}$ & \\
\hline Briza maxima $\mathrm{L}$. & Tembladera & Poaceae & $\mathrm{Te}$ & $\mathrm{I}$ & \\
\hline Briza minor $\mathrm{L}$. & Pasto perdiz & Poaceae & $\mathrm{Te}$ & $\mathrm{I}$ & \\
\hline Bromus catharticus Vahl & Pasto lanco & Poaceae & $\mathrm{Hc}$ & $\mathrm{N}$ & \\
\hline Bromus hordeaceus L. & Bromo, cebadilla & Poaceae & Te & $\mathrm{I}$ & \\
\hline Calydorea xiphioides (Poepp.) Espinosa & Tahay, violeta & Iridaceae & $\mathrm{Cr}$ & $\mathrm{E}$ & $\mathbf{P}$ \\
\hline Carex excelsa Poepp. ex Kunth & Cortadera & Cyperaceae & $\mathrm{Cr}$ & $\mathrm{N}$ & \\
\hline Carex setifolia Kunze ex Kunth & Cortadera & Cyperaceae & $\mathrm{Cr}$ & $\mathrm{N}$ & \\
\hline Carex sp. & S.n. & Cyperaceae & $\mathrm{Cr}$ & $\mathrm{N}$ & \\
\hline Chascolytrum subaristatum (Lam.) Desv. & Tembladera & Poaceae & Te & $\mathrm{N}$ & \\
\hline Chloraea barbata Lindl. & Orquídea & Orchidaceae & $\mathrm{Cr}$ & E & \\
\hline Chloraea bletioides Lindl. & Lengua de loro & Orchidaceae & $\mathrm{Cr}$ & E & \\
\hline Chloraea chrysantha Poepp. & Orquídea & Orchidaceae & $\mathrm{Cr}$ & E & \\
\hline Chloraea cylindrostachya Poepp. & Orquídea & Orchidaceae & $\mathrm{Cr}$ & $\mathrm{N}$ & \\
\hline Chloraea disoides Lindl. var. picta & Orquídea & Orchidaceae & $\mathrm{Cr}$ & $\mathrm{N}$ & $\mathbf{V}$ \\
\hline Chloraea galeata Lindl. & Orquídea & Orchidaceae & $\mathrm{Cr}$ & $\mathrm{E}$ & \\
\hline Chloraea heteroglossa Rchb. f. & Orquídea & Orchidaceae & $\mathrm{Cr}$ & E & $\mathbf{V}$ \\
\hline Chloraea incisa Poepp. & Orquídea & Orchidaceae & $\mathrm{Cr}$ & E & \\
\hline Chloraea multiflora Lindl. & Orquídea & Orchidaceae & $\mathrm{Cr}$ & E & \\
\hline Chloraea virescens (Willd.) Lindl. & Orquídea & Orchidaceae & $\mathrm{Cr}$ & $\mathrm{N}$ & \\
\hline Chusquea cumingii Nees & Coligüe, quila & Poaceae & $\mathrm{Nf}$ & $\mathrm{E}$ & \\
\hline Conanthera bifolia Ruiz et Pav. & Pajarito del campo & Tecophilaeaceae & $\mathrm{Hc}$ & E & \\
\hline Conanthera campanulata (D.Don) Lindl. & Flor de la viuda & Tecophilaeaceae & Hc & E & \\
\hline Conanthera trimaculata (D.Don) F.Meigen & Flor de la viuda & Tecophilaeaceae & $\mathrm{Hc}$ & $\mathrm{E}$ & $\mathbf{V}$ \\
\hline Cynodon dactylon (L.) Pers. & Pasto bermuda & Poaceae & $\mathrm{Hc}$ & $\mathrm{I}$ & \\
\hline Cynosurus echinatus L. & Cola de zorro & Poaceae & Te & $\mathrm{I}$ & \\
\hline Cyperus eragrostis Lam. var. compactus & Cortadera & Cyperaceae & $\mathrm{Cr}$ & $\mathrm{N}$ & \\
\hline Cyperus eragrostis Lam. var. eragrostis & Cortadera & Cyperaceae & $\mathrm{Cr}$ & $\mathrm{N}$ & \\
\hline Dioscorea parviflora Phil. & Papa cimarrona & Dioscoreaceae & $\mathrm{Cr}$ & $\mathrm{N}$ & \\
\hline Dioscorea saxatilis Poepp. & Papa cimarrona & Dioscoreaceae & $\mathrm{Cr}$ & $\mathrm{N}$ & \\
\hline Distichlis spicata (L.) Greene & Pasto salado & Poaceae & $\mathrm{Cr}$ & $\mathrm{N}$ & \\
\hline Echinochloa colonum (L.) Link & Hualcacho & Poaceae & Te & $\mathrm{N}$ & \\
\hline Eleocharis pachycarpa E.Desv. & Rume & Cyperaceae & $\mathrm{Hc}$ & $\mathrm{N}$ & \\
\hline Eleocharis radicans (Poir.) Kunth & Rume & Cyperaceae & $\mathrm{Hc}$ & $\mathrm{N}$ & \\
\hline Elodea potamogeton (Bertero) Espinosa & Luchecillo & Hydrocharitaceae & $\mathrm{Cr}$ & $\mathrm{N}$ & \\
\hline Eragrostis virescens J.Presl. & S.n & Poaceae & Te & $\mathrm{N}$ & \\
\hline Festuca sp. & Coirón & Poaceae & Hc & $\mathrm{N}$ & \\
\hline
\end{tabular}




\begin{tabular}{|c|c|c|c|c|c|}
\hline Classification / Scientific name & Common name & Family & FV & $\mathrm{OF}$ & EC \\
\hline $\begin{array}{l}\text { Gastridium phleoides (Nees et Meyen) } \\
\text { C.E.Hubb. }\end{array}$ & s.n & Poaceae & $\mathrm{Te}$ & $\mathrm{I}$ & \\
\hline Gavilea venosa (Lam.) Garay et Ormd. & Orquídea & Orchidaceae & $\mathrm{Cr}$ & $\mathrm{N}$ & \\
\hline Gavilea leucantha Poepp. et Endl. & Orquídea & Orchidaceae & $\mathrm{Cr}$ & $\mathrm{N}$ & \\
\hline $\begin{array}{l}\text { Gavilea longibracteata (Lindl.) Sparre ex } \\
\text { L.E.Navas }\end{array}$ & Orquídea & Orchidaceae & $\mathrm{Cr}$ & $\mathrm{E}$ & \\
\hline Gilliesia graminea Lindl. & Junquillo & Alliaceae & $\mathrm{Cr}$ & $\mathrm{N}$ & \\
\hline Herbertia lahue (Molina) Goldblat & Lahue & Iridaceae & $\mathrm{Cr}$ & $\mathrm{N}$ & $\mathbf{V}$ \\
\hline Hordeum chilense Roem. et Schult. & Cebadilla & Poaceae & $\mathrm{Hc}$ & $\mathrm{N}$ & \\
\hline Hordeum murinum L. & Cebadilla & Poaceae & $\mathrm{Te}$ & $\mathrm{I}$ & \\
\hline Isolepis cernua (Vahl) Roem. et Schult. & S.n & Cyperaceae & $\mathrm{Cr}$ & $\mathrm{N}$ & \\
\hline Jubaea chilensis Baill. & Palma de coquitos & Arecaceae & $\mathrm{F}$ & $\mathrm{E}$ & $\mathbf{V}$ \\
\hline Juncus acutus L. & Junquillo & Juncaceae & $\mathrm{Hc}$ & $\mathrm{N}$ & \\
\hline Juncus bufonius L. & Junquillo & Juncaceae & $\mathrm{Te}$ & $\mathrm{I}$ & \\
\hline Juncus cyperoides Laharpe & Junco & Juncaceae & $\mathrm{Hc}$ & $\mathrm{N}$ & \\
\hline Juncus imbricatus Laharpe & Junquillo & Juncaceae & $\mathrm{Cr}$ & $\mathrm{N}$ & \\
\hline Juncus pallescens Lam. & Junco & Juncaceae & $\mathrm{Hc}$ & $\mathrm{N}$ & \\
\hline Juncus stipulatus Nees et Meyen & Junco & Juncaceae & $\mathrm{Hc}$ & $\mathrm{N}$ & \\
\hline Lemna valdiviana Phil. & Lenteja de agua & Lemnaceae & $\mathrm{Cr}$ & $\mathrm{N}$ & \\
\hline Leucocoryne ixioides (Sims) Lindl. & Huilli & Alliaceae & $\mathrm{Cr}$ & E & $\mathbf{V}$ \\
\hline Leucocoryne violacescens Phil. & Huilli & Alliaceae & $\mathrm{Cr}$ & E & $\mathbf{V}$ \\
\hline Lolium multiflorum Lam. & Ballica italiana & Poaceae & $\mathrm{Te}$ & $\mathrm{I}$ & \\
\hline Lolium perenne L. & Ballica inglesa & Poaceae & Hc & $\mathrm{I}$ & \\
\hline Luzula racemosa Desv. & Lúzula & Juncaceae & $\mathrm{Cr}$ & $\mathrm{N}$ & \\
\hline Melica longiflora Steud. & s.n & Poaceae & $\mathrm{Hc}$ & E & \\
\hline Melica violacea Cav. & S.n & Poaceae & $\mathrm{Te}$ & $\mathrm{N}$ & \\
\hline Nassella chilensis (Trin.) E.Desv. & Coironcillo & Poaceae & Hc & E & \\
\hline Nassella gigantea (Steud.) M.Muñoz & s.n & Poaceae & Hc & $\mathrm{N}$ & \\
\hline Nassella manicata (Desv.) Barkworth & s.n & Poaceae & $\mathrm{Hc}$ & $\mathrm{N}$ & \\
\hline Nothoscordum gramineum (Sims) Beauverd & Huilli de perro & Alliaceae & $\mathrm{Cr}$ & $\mathrm{N}$ & \\
\hline $\begin{array}{l}\text { Olsynium junceum (E.Mey. ex C.Presl) } \\
\text { Goldblatt }\end{array}$ & Huilmo, ñuño & Iridaceae & $\mathrm{Cr}$ & $\mathrm{N}$ & \\
\hline Oziroe biflora (Ruiz et Pav.) Speta & Cebolleta & Hyacinthaceae & $\mathrm{Cr}$ & $\mathrm{N}$ & \\
\hline Pasithea caerulea (Ruiz et Pav.) D.Don & Azulillo & Anthericaceae & $\mathrm{Cr}$ & $\mathrm{N}$ & \\
\hline Paspalum dilatatum Poir. & Chépica gigante & Poaceae & $\mathrm{Cr}$ & $\mathrm{N}$ & \\
\hline Paspalum vaginatum $\mathrm{Sw}$. & Chépica & Poaceae & $\mathrm{Cr}$ & $\mathrm{N}$ & \\
\hline Phleum pratense $\mathrm{L}$. & s.n & Poaceae & $\mathrm{Hc}$ & $\mathrm{I}$ & \\
\hline Phycella bicolor Herb. & Añañuca & Amaryllidaceae & $\mathrm{Cr}$ & E & $\mathbf{V}$ \\
\hline Phycella ignea (Lindl.) Lindl. & Añañuca de fuego & Amaryllidaceae & $\mathrm{Cr}$ & $\mathrm{E}$ & \\
\hline $\begin{array}{l}\text { Piptochaetium montevidense (Spreng.) } \\
\text { Parodi }\end{array}$ & s.n & Poaceae & Hc & $\mathrm{N}$ & \\
\hline Piptochaetium panicoides (Lam.) Desv. & s.n & Poaceae & $\mathrm{Hc}$ & $\mathrm{N}$ & \\
\hline $\begin{array}{l}\text { Piptochaetium stipoides (Trin. et Rupr.) } \\
\text { Hackel }\end{array}$ & S.n & Poaceae & Te & $\mathrm{N}$ & \\
\hline
\end{tabular}


Wealth of Flora and Vegetation

in the La Campana-Peñuelas Biosphere Reserve, Valparaiso Region, Chile

\begin{tabular}{|c|c|c|c|c|c|}
\hline Classification / Scientific name & Common name & Family & FV & OF & EC \\
\hline Placea ornata Miers & Macaya & Amaryllidaceae & $\mathrm{Cr}$ & E & \\
\hline Poа anпиа L. & Pasto piojillo & Poaceae & $\mathrm{Te}$ & $\mathrm{I}$ & \\
\hline Potamogeton pusillus L. & Huiro & Potamogetonaceae & $\mathrm{Cr}$ & $\mathrm{N}$ & \\
\hline Puya berteroana Mez. & Chagual & Bromeliaceae & $\mathrm{Hc}$ & $\mathrm{N}$ & \\
\hline Puya chilensis Molina & Chagual, cardón & Bromeliaceae & Hc & $\mathrm{N}$ & $\mathbf{V}$ \\
\hline Puya coerulea Lindl. & Chagual chico & Bromeliaceae & Hc & E & \\
\hline Rhodophiala advena (Ker Gawl.) Traub. & Añañuca & Amaryllidaceae & $\mathrm{Cr}$ & E & \\
\hline Rostraria cristata (L.) Tzvelev & S.n & Poaceae & $\mathrm{Te}$ & $\mathrm{I}$ & \\
\hline $\begin{array}{l}\text { Schoenoplectus californicus (C.A.Mey.) } \\
\text { Soják }\end{array}$ & Totora, estoquilla & Cyperaceae & $\mathrm{Cr}$ & $\mathrm{N}$ & \\
\hline Scirpus asper J.Presl et C.Presl & S.n & Cyperaceae & $\mathrm{Cr}$ & $\mathrm{N}$ & \\
\hline Setaria parviflora (Poir.) Kerguélen & S.n & Poaceae & Hc & $\mathrm{N}$ & \\
\hline Sisyrinchium arenarium Poepp. & Huilmo, ñuño & Iridaceae & $\mathrm{Hc}$ & E & \\
\hline Sisyrinchium chilense Hook. & Huilmo, ñuño & Iridaceae & $\mathrm{Hc}$ & E & \\
\hline Sisyrinchium cuspidatum Poepp. & Huilmo, ñuño & Iridaceae & $\mathrm{Hc}$ & E & \\
\hline $\begin{array}{l}\text { Solenomelus pedunculatus (Guillies ex } \\
\text { Hook.) Hochr. }\end{array}$ & Maicillo & Iridaceae & Hc & $\mathrm{N}$ & \\
\hline Solenomelus segethii (Phil.) Kunze & Clavelillo & Iridaceae & $\mathrm{Hc}$ & $\mathrm{N}$ & \\
\hline Stipa sp. & Flechilla & Poaceae & $\mathrm{Hc}$ & $\mathrm{N}$ & \\
\hline Tecophilaea violiflora Bertero ex Colla & Violeta hojas largas & Tecophilaeaceae & $\mathrm{Hc}$ & $\mathrm{N}$ & \\
\hline Tillandsia usneoides L. & Barba de viejo & Bromeliaceae & $\mathrm{Fe}$ & $\mathrm{N}$ & \\
\hline $\begin{array}{l}\text { Trichopetalum plumosum (Ruiz et Pav.) } \\
\text { J.F.Macbr. }\end{array}$ & $\begin{array}{l}\text { Flor de la } \\
\text { plumilla }\end{array}$ & Anthericaceae & $\mathrm{Cr}$ & $\mathrm{N}$ & \\
\hline Tristagma bivalve (Lindl.) Traub & S.n & Alliaceae & $\mathrm{Cr}$ & $\mathrm{N}$ & \\
\hline Typha angustifolia L. & Vatro & Typhaceae & $\mathrm{Cr}$ & $\mathrm{N}$ & \\
\hline Uncinia trichocarpa C.A.Mey. & Clin clin & Cyperaceae & Hc & $\mathrm{N}$ & \\
\hline Vulpia bromoides (L.) Gray & Pasto sedilla & Poaceae & $\mathrm{Te}$ & $\mathrm{I}$ & \\
\hline Vulpia myuros (L.) C.C.Gmel. & Pasto sedilla & Poaceae & $\mathrm{Te}$ & $\mathrm{I}$ & \\
\hline
\end{tabular}

Table 2. Checklist of the flora of La Campana-Peñuelas Biosphere Reserve (FV = life form,

$\mathrm{OF}=$ geographic origin, $\mathrm{EC}=$ condition of conservation, $\mathrm{F}=$ phanerophyte,

$\mathrm{Nf}=$ nanophanerophyte, $\mathrm{Hc}=$ hemicryptophyte, $\mathrm{Cr}=$ cryptophyte, $\mathrm{C}=$ chamaephyte,

$\mathrm{Te}=$ terophyte, $\mathrm{Fe}=$ epiphyte, $\mathrm{Ft}=$ vine, $\mathrm{Fp}=$ parasite, $\mathrm{N}=$ native, $\mathrm{I}=$ introduced,

$\mathrm{P}=$ threatened, $\mathrm{R}=$ rare, $\mathrm{V}=$ vulnerable, $\mathrm{IC}=$ insufficiently known).

\section{Acknowledgements}

Thanks to the staff and park wardens of CONAF, Valparaiso Region, for their support in field activities and for facilitating the photographies, bibliographic and cartographic information.

\section{References}

Aguilella, A.; Amigo, J. (2001). Vegetation transects in central-southern Chile. In: GómezMercado, T. \& Mota-Poveda, J. eds. Vegetación y cambios climáticos. Spain. University of Almería. pp. 87-101. 
Araya, S. \& Avila, G. (1981). New shoot production in shrubs affected by fire in "Chilean scrub". Anales del Museo de Historia Natural de Valparaíso 14:99-105.

Armesto, J.; Papic, C. \& Pliscoff, P. (2002). Importance of small wilderness areas for the conservation of biodiversity in native forest. Ambiente y Desarrollo 18:44-50.

Arroyo, MTK.; Cavieres, L.; Marticorena, C. \& Muñoz, M. (1995). Convergence in the mediterranean floras of central Chile and California: Insights from comparative biogeography. In: Arroyo, MTK.; Fox, M. \& Zedler, P. eds. Ecology and biogeography of mediterranean ecosystems in Chile, California, and Australia. New York. SpringerVerlag. pp. 43-88.

Arroyo, MTK.; Matthei, O.; Marticorena, C.; Muñoz, M.; Pérez, F. \& Humaña, AM. (2000). The vascular plant flora of the Bellotos del Melado National Reserve, VII Region, Chile: a documented checklist. Gayana Botánica 57:117-139.

Arroyo, MTK.; Matthei, O.; Muñoz-Schick, M.; Armesto, JJ.; Pliscoff, P.; Pérez, F. \& Marticorena, C. (2005). Flora of four National Reserves in the Coastal Range of the VII Region $\left(35^{\circ}-36^{\circ} \mathrm{S}\right)$, Chile, and its role in the protection of regional biodiversity. In: Smith-Ramírez, C.; Armesto, JJ. \& Valdovinos C. eds. Historia, biodiversidad y ecología de los bosques costeros de Chile. Santiago, Chile. Editorial Universitaria. pp. 225-244.

Avila, G.; Aljaro, ME. \& Silva, B. (1981). Observations in the herbaceous stratum of scrub after fire. Anales Museo de Historia Natural de Valparaíso 14:107-113.

Baeza, M.; Barrera, E.; Flores, J.; Ramírez, C. \& R. Rodríguez. 1998. Conservation categories of native Chilean Pteridophyta. Boletín Museo Nacional de Historia Natural, Chile 47: 23-46.

Balduzzi, A.; Serey, I.; Tomaselli, R. \& Villaseñor, R. (1981). New phytosociological observations on the mediterranean type of climax vegetation of central Chile. Atti Istituto Botanico Laboratori Crittogamico di Pavia, serie 6, 14:93-112.

Balduzzi A.; Tomaselli, R.; Serey, I. \& Villaseñor, R. (1982). Degradation of the mediterranean type of vegetation in central Chile. Ecología Mediterránea 8:223-240.

Belmonte, E.; Faúndez, L.; Flores, J.; Hoffmann, A.; Muñoz, M. \& Teillier, S. (1998). Conservation categories of native Chilean cactaceae. Boletín Museo Nacional de Historia Natural, Chile 47:69-89.

Benoit, IL. ed. 1989. Red book of Chilean terrstrial flora. Santiago, Chile. CONAF. 157 pp.

Braun-Blanquet, J. (1964). Plant sociology - features of phytosociology. Wien. Springer Verlag. $865 \mathrm{pp}$.

Braun-Blanquet, J. 1979. Phytosociology. Basis for the study of plant communities. Madrid. Blume. 686 pp.

Cabrera, AL. \& Willink, A. (1973). Biogeography of Latin America. Washington D.C. Biology Series, Monograph $N^{\circ} 13$, Regional Program for Scientific and Technological Development, Departament of Scientific Affairs, General Secretariat of the Organization of American States. 120 pp.

Cavieres, LA.; Mihoc, M.; Marticorena, A.; Marticorena, C.; Matthei, O. \& Squeo, FA. (2001). Determination of priority areas for conservation: Parsimony Analysis of Endemicity (PAE) in the flora of the IV (Coquimbo) Region. In: Squeo FA, G Arancio, JR Gutiérrez eds. Libro rojo de la flora nativa y de los sitios prioritarios para su conservación: Región de Coquimbo. La Serena, Chile. University of La Serena. pp. 159170. 
CONAF (Corporación Nacional Forestal). (1986). Management plan, Lago Peñuelas Forest Reserve. Santiago, Chile. National Forest Corporation. Working Document N 77. 20 pp.

CONAF (Corporación Nacional Forestal). (1992). National Parks and Natural Monuments of Chile. Santiago, Chile. National Forest Corporation. 2 pp.

CONAF (Corporación Nacional Forestal). (1994). Report on the floral wealth of the Bajo los Lirios sector. Lago Peñuelas National Reserve. Santiago, Chile. National Forest Corporation. Technical Bulletin u/n. 15 pp.

CONAF (Corporación Nacional Forestal). (2008). Biosphere Reserve La Campana-Peñuelas (Offer of Extension). Document bases MAB Program - UNESCO. National Forest Corporation, Region of Valparaiso, Chile. $188 \mathrm{pp}$.

CONAF \& CONAMA (Corporación Nacional Forestal, CL - Comisión Nacional del Medio Ambiente, CL). (1999). Register and evaluation of Chilean native vegetation resources. Regional Report, Fifth Region. Santiago, Chile. Project CONAF-CONAMA-BIRF. $141 \mathrm{pp}$.

DI Castri, F. \& Hajek, E. (1976). Bioclimatology of Chile. Santiago, Chile. Catholic University of Chile. 128 pp.

Ellenberg, H. \& Mueller-Dombois, D. (1966). A key to Raunkiaer plant life forms with revised subdivisions. Ber. Geob. Inst. ETH Stiftung Rubel, Zurich 37:56-73.

Elórtegui, S. \& Moreira-Muñoz, A. eds. (2002). La Campana National Park: Origin of a Biosphere Reserve in central Chile. Santiago, Chile. Taller La Era. 176 pp.

Gajardo, R. (1995). Chile's natural vegetation. Classification and distribution. Santiago, Chile. Editorial Universitaria. $165 \mathrm{pp}$.

González, A. (2000). Evaluation of vegetation resources in the Budi river basin, current situation and proposals for management. Degree Thesis in Natural Resources. Temuco, Chile. Faculty of Sciences, Catholic University of Temuco. 110 pp.

Grau, J. (1992). The central zone of Chile. In: Grau, J. \& Zizka, G. eds. Chilean wild flora. Palms, special volume 19: 1-154.

Grigera, D.; Brion, C.; Chiapella, JO. \& Pillado, MS. (1996). Plant life forms as indicators of environmental factors. Medio Ambiente 13:11-29.

Hauenstein, E.; Ramírez, C.; Latsague, M. \& Contreras, D. (1988). Phytogeographic origin and biological spectrum as a means for measuring the degree of human intervention in plant communities. Medio Ambiente 9:140-142.

Hauenstein, E.; González, M.; Peña, F. \& Muñoz, A. (2002). Classification and characterization of the flora and vegetation coastal wetlands of Tolten (IX Region, Chile). Gayana Botánica 59:87-100.

Hauenstein, E.; González, M.; Peña-Cortés, F. \& Muñoz-Pedreros, A. (2005a). Plant diversity in coastal wetlands of the Araucanía Region. In: Smith-Ramírez, C.; Armesto, JJ. \& Valdovinos, C. eds. Historia, biodiversidad y ecología de los bosques costeros de Chile. Santiago, Chile. Editorial Universitaria. pp. 197-205.

Hauenstein, E.; González, M.; Peña-Cortés, F. \& Falcón, L. (2005b). Indicator plants for eutrophisation in lakes of southern Chile. In: Vila, I. \& Pizarro, J. eds. Eutrofización de lagos y embalses. Iberoamerican Programme of Science and Technology for Development Desarrollo (CYTED - University of Chile). Santiago, Chile. Patagonia Impresores. pp. 119-133. 
Hauenstein, E.; Muñoz-Pedreros, A.; Yáñez, J.; Sánchez, P.; Möller, P.; Guiñez, B. \& Gil, C. (2009). Flora and vegetation of the Peñuelas Lake National Reserve. Biosphere Reserve, Region of Valparaiso, Chile. BOSQUE 30(3): 159-179.

Hoffmann, A. (1978). Wild flora of Chile, central zone. 1st ed. Santiago, Chile. Claudio Gay Foundation. 255 pp.

Hoffmann, A. (1991). Wild flora of Chile, Araucana zone. 2nd ed. Santiago, Chile. Claudio Gay Foundation. 257 pp.

Hoffmann, A.; Arroyo, MK.; Liberona, F.; Muñoz, M. \& Watson, J. (1998). High Andean plants in the wild flora of Chile. Santiago, Chile. Claudio Gay Foundation. 281 pp.

ICSA (Ingenieros Consultores Asociados S.A.). (1980). Study of proposals for integrated development potential of the Lago Peñuelas Forest Reserve. Santiago, Chile. ICSACONAF. 187 pp.

IPNI (International Plant Names Index). (2011). The International Plant Names Index. Consulted 10 Jul 2011. Available at http://www.ipni.org/

Koeppen, W. (1931). The earth's climate. Berlin. Outline of climatology. $182 \mathrm{pp}$.

Koeppen, W. (1948). Climatology. Mexico. Economic Culture Fund. 350 pp.

Looser, G. (1927). Nothofagus, Cyttaria and Myzodendron on El Roble mountain. Revista Chilena de Historia Natural 31: 288-290.

Looser, G. (1944). Phytosociological notes on the Quintero region. Revista Universitaria 29: 27-33.

Luebert, F. \& Becerra, P. (1998). Plant representativeness of the National System for StateProtected Wilderness Areas (SNASPE) in Chile. Ambiente y Desarrollo 14(2):62-69.

Luebert, F. \& Pliscoff, P. (2006). Bioclimate and vegetation synopsis of Chile. Santiago, Chile. Editorial Universitaria. 307 pp.

Marticorena, C. \& Quezada, M. (1985). Catalogue of the vascular flora of Chile. Gayana Botánica 42:1-155.

Marticorena, C \& Rodríguez, R. eds. (1995). Flora of Chile. Vol. 1. Pteridophyta- Gymnospermae. Concepción, Chile. University of Concepción. 351 pp.

Marticorena, C. \& Rodríguez, R. eds. (2001). Flora of Chile. Vol. 2(1) .WinteraceaeRanunculaceae. Concepción, Chile. University of Concepción. 99 pp.

Marticorena, C \& Rodríguez, R. eds. (2003). Flora of Chile. Vol. 2(2). Berberidaceae-Betulaceae. Concepción, Chile. University of Concepción. 93 pp.

Marticorena, C. \& Rodríguez, R. eds. (2005). Flora of Chile.Vol. 2(3). Plumbaginaceae Malvaceae. Concepción, Chile. University of Concepción. 128 pp.

Marticorena, C.; Von Bohlen, C.; Muñoz, M. \& Arroyo, MK. (1995). Dicotyledons. In: Simonetti, JA. \& Arroyo, MK.; Spotorno, AE. \& Lozada, E. eds. Biological diversity of Chile. Santiago, Chile. Artegrama. pp. 77-89.

Matthei, O. (1995). Manual of the weeds which grow in Chile. Santiago, Chile. Alfabeta Impresores. $545 \mathrm{pp}$.

Mittermeier, RA.; Myers, N.; Thomsen, JB.; Da Fonseca, GA. \& Olivieri, S. (1998). Biodiversity hotspots and major tropical wilderness area: approaches to setting conservation priorities. Conservation Biology 12:516-520.

Montenegro, G.; Aljaro, ME. \& Kummerow, J. (1979). Growth dynamics of Chilean matorral shrubs. Botanical Gazette 140:114-119. 
Mooney, HA. \& Kummerow, J. (1971). The comparative water economy of representative evergreen sclerophyll and drought deciduous shrubs of Chile. Botanical Gazette 132:246-252.

Muñoz, C. (1966). Synopsis of Chilean flora. 2nd ed. Santiago, Chile. University of Chile. 500 pp.

Muñoz, M. \& Moreira, A. (2003). Alstroemerias de Chile: diversidad, distribución y conservación. Santiago, Chile. Taller La Era. 139 pp.

Myers, N.; Mittermeier, RA.; Mittermeier, CG.; Da Fonseca, GA. \& Kent, J. (2000). Biodiversity hotspots for conservation priorities. Nature 403: 853-858.

Navas, ME. (1973). Flora of the Santiago basin, Chile. Vol I. Santiago, Chile. University of Chile. 299 pp.

Navas, ME. (1976). Flora of the Santiago basin, Chile. Vol II. Santiago, Chile. University of Chile. 559 pp.

Navas, ME. (1979). Flora of the Santiago basin, Chile. Vol III. Santiago, Chile. University of Chile. 509 pp.

Novoa, P.; Espejo, J.; Cisternas, M.; Rubio, M. \& Dominguez, E. (2006). Field guide to Chilean orchids. Concepción, Chile. Corporación Chilena de la Madera. 120 pp.

Oberdorfer, E. (1960). Plant sociology studies in Chile - A comparison with Europe. Weinheim. Cramer. 208 pp.

Oltremari, J. (2002). Protected areas and the conservation of biological diversity. Santiago, Chile. Catholic University of Chile. 11 pp.

Palma, B.; San Martín, C.; Rosales, M.; Zúñiga, L. \& Ramírez, C. (1978). Spatial distribution of aquatic and marsh flora and vegetation of the Marga-Marga river in central Chile. Anales del Instituto de Ciencias del Mar y Limnología Universidad Nacional Autónoma de México 14(2):125-132.

Pisano, E. (1956). Scheme for the classification of plant communities in Chile. Agronomía 2:30-33.

Ramírez, C. (1988). Life forms, phytoclimates and plant formations. El Arbol Nuestro Amigo 4:33-37.

Ramírez, C. \& Añazco, N. (1982). Seasonal variations in the development of Scirpus californicus, Typha angustifolia and Phragmites communis in Valdivian swamps, Chile. Agro Sur 10:111-123.

Ramírez, C. \& Westermeier, R. (1976). Study of the spontaneous vegetation of the Botanic Garden of the Austral University of Chile (Valdivia), as an example of phytosociological tabulation. Agro Sur 4:93-105.

Ramírez, C.; San Martín, C. \& San Martín, J. (1996). Floral structure of the swamp forests of central Chile. In: Armesto, JJ.; Arroyo, MK. \& Villagrán, C. eds. Ecología de los bosques nativos de Chile. Santiago, Chile. Editorial Universitaria. pp. 215-234.

Ramírez, C.; San Martín, J.; San Martín, C. \& Contreras, D. (1987). Floral and vegetation study of El Peral lake, Fifth Region, Chile. Revista Geográfica de Valparaíso 18:105120.

Ravenna, P.; Teillier, S.; Macaya, J.; Rodríguez, R. \& Zöllner, O. (1998). Conservation categories of Chilean native bulb plants. Boletín Museo Nacional de Historia Natural, Chile 47:47-68.

Riedemann, P. \& Aldunate, G. (2001). Native flora of ornamental value, identification and propagation. Chile, central zone. Santiago, Chile. Andrés Bello. 566 p. 
Rodríguez, A. (1979). Plant formations of the Campanita Range. Boletín Informativo Instituto Geográfico Militar Chile, IV Trimestre 1979: 11-31.

Rodríguez, A. (1982). Principal plant formations of La Campana National Park. Boletín Informativo Instituto Geográfico Militar Chile, I Trimestre 1982: 11-31.

Rodríguez, A. \& Calderón, F. (1982). Determination of plant structures on La Campana mountain. Boletín Informativo Instituto Geográfico Militar Chile, II Trimestre 1982: 2947.

Roussine, N. \& Negre, R. (1952). Plant groupings of mediterranean France. Montpellier. CNRS. 297 pp.

Rundel, P. \& Weisser, P. (1975). La Campana, a new National Park in Central Chile. Biological Conservation 8: 35-46.

San Martín, C.; Medina, R.; Ojeda, P. \& Ramírez, C. (1993). Plant biodiversity in the Río Cruces Nature Sanctuary (Valdivia, Chile). Acta Botanica Malacitana 18:259-279.

San Martín, C.; Ramírez, C. \& Rubilar, H. (2002). Ecophysiology of saw-sedge marshes in Valdivia, Chile. Ciencia e Investigación Agraria 29:171-179.

Simonetti, JA. (1995). Biological diversity: something more than names, something more than numbers. In: Simonetti, JA.; Arroyo, MK.; Spotorno, AE. \& Lozada, E. eds. Diversidad biológica de Chile. Santiago, Chile. Artegrama. pp. 1-4.

Simonetti, JA. (2004). Connect to conserve. Ambiente y Desarrollo 20:2-4.

Strang, C. (1983). The birds of Peñuelas lake. Chile Forestal 95:20-22.

Steubing, L.; Ramírez, C. \& Alberdi, M. (1980). Energy content of water and bog plant associations in the region of Valdivia (Chile). Vegetatio 43:153-161.

Steubing, L.; Godoy, R. \& Alberdi, M. (2002). Plant ecology methods. Valdivia, Chile. University texts collection, Austral University of Chile. 345 pp.

Teillier, S. (2003). Flora of the El Morado Natural Monument: Addenda et Corrigenda. Gayana Botánica 60:94-101.

Teillier, S.; Aldunate, G.; Riedemann, P. \& Niemeyer, H. (2005). Flora of the Río Clarillo National Reserve. Guide to species identification. Santiago, Chile. Impresos Socías. 367 pp.

Villaseñor, R. (1980). Physionomic and floral units of the La Campana National Park. Anales del Museo de Historia Natural de Valparaíso 13:65-70.

Villaseñor, R. (1986). Guide to the recognition of the most frequent tree and shrub species in La Campana National Park. Valparaíso, Chile. CONAF - University of Playa Ancha. 190 pp.

Villaseñor, R. \& Serey, I. (1980-1981). Phytosociological study of the vegetation of La Campana mountain (La Campana National Park) in central Chile. Atti Ist. Bot. Lab. Critt. Univ. Pavia 6:69-91.

Weber, C. (1986). Conservation and rational use of nature in protected areas. Ambiente $y$ Desarrollo 2:165-181.

WWF. \& IUCN. (1997). Centres of plant diversity: a guide and strategy for their conservation. The Americas. IUCN Publications Units, Cambridge, United Kingdom Vol. 3.

Zöllner, O.; Olivares, M. \& Varas, ME. (1995). The genus Fumaria L. (Fumariaceae) in the central zone of Chile. Anales del Museo de Historia Natural de Valparaíso 23: 21-31. 


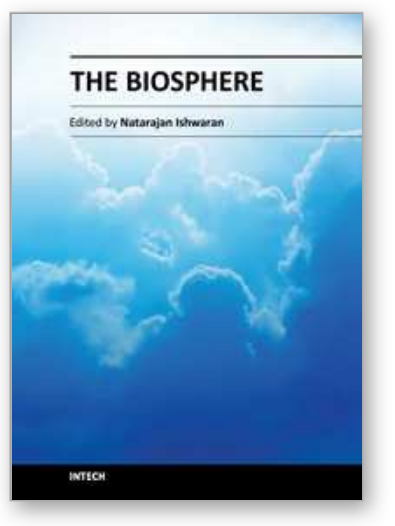

\author{
The Biosphere \\ Edited by Dr. Natarajan Ishwaran
}

ISBN 978-953-51-0292-2

Hard cover, 302 pages

Publisher InTech

Published online 14, March, 2012

Published in print edition March, 2012

In this book entitled "The Biosphere", researchers from all regions of the world report on their findings to explore the origins, evolution, ecosystems and resource utilization patterns of the biosphere. Some describe the complexities and challenges that humanity faces in its efforts to experiment and establish a new partnership with nature in places designated as biosphere reserves by UNESCO under its Man and the Biosphere (MAB) Programme. At the dawn of the 21st century humanity is ever more aware and conscious of the adverse consequences that it has brought upon global climate change and biodiversity loss. We are at a critical moment of reflection and action to work out a new compact with the biosphere that sustains our own wellbeing and that of our planetary companions. This book is a modest attempt to enrich and enable that special moment and its march ahead in human history.

\title{
How to reference
}

In order to correctly reference this scholarly work, feel free to copy and paste the following:

Enrique Hauenstein (2012). Wealth of Flora and Vegetation in the La Campana-Peñuelas Biosphere Reserve, Valparaiso Region, Chile, The Biosphere, Dr. Natarajan Ishwaran (Ed.), ISBN: 978-953-51-0292-2, InTech, Available from: http://www.intechopen.com/books/the-biosphere/richness-of-flora-and-vegetation-of-thebiosphere-reserve-la-campana-pe-uelas-region-of-valparaiso-c

\section{INTECH}

open science | open minds

\author{
InTech Europe \\ University Campus STeP Ri \\ Slavka Krautzeka 83/A \\ 51000 Rijeka, Croatia \\ Phone: +385 (51) 770447 \\ Fax: +385 (51) 686166 \\ www.intechopen.com
}

\author{
InTech China \\ Unit 405, Office Block, Hotel Equatorial Shanghai \\ No.65, Yan An Road (West), Shanghai, 200040, China \\ 中国上海市延安西路65号上海国际贵都大饭店办公楼405单元 \\ Phone: +86-21-62489820 \\ Fax: $+86-21-62489821$
}


(C) 2012 The Author(s). Licensee IntechOpen. This is an open access article distributed under the terms of the Creative Commons Attribution 3.0 License, which permits unrestricted use, distribution, and reproduction in any medium, provided the original work is properly cited. 